\title{
Calcium Channels in Retinal Function and Disease
}

Brittany Williams ${ }^{1}$, J. Wesley Maddox², and Amy Lee ${ }^{2, *}$

${ }^{1}$ Dept. of Cell Biology \& Physiology, Carolina Institute for Developmental Disabilities, and Neuroscience Center, University of North Carolina, Chapel Hill

${ }^{2}$ Department of Neuroscience, University of Texas-Austin

*To whom correspondence should be addressed:

Department of Neuroscience

University of Texas-Austin

100 E $24^{\text {TH }}$ ST, NHB 3.139

Austin, TX 78712-1597

\section{Email: amy.lee1@austin.utexas.edu}

Tel: (512) 232-7594

When citing this paper, please use the following: Williams, B., Maddox, J.W., Lee, A. Calcium Channels in Retinal Function and Disease. Annu. Rev. Vis. Sci. Submitted. DOI: 10.1146/annurev-vision-012121-111325

\begin{abstract}
Voltage-gated $\mathrm{Ca}^{2+}\left(\mathrm{Ca}_{\mathrm{v}}\right)$ channels play pivotal roles in regulating gene transcription, neuronal excitability, and neurotransmitter release. In order to meet the spatial and temporal demands of visual signaling, $\mathrm{Ca}_{\mathrm{v}}$ channels exhibit unusual properties in the retina compared to their counterparts in other areas of the nervous system. Here, we review current concepts regarding the specific subtypes of $\mathrm{Ca}_{\mathrm{v}}$ channels expressed in the retina, their intrinsic properties and forms of modulation, and how their dysregulation could lead to retinal disease.
\end{abstract}

Keywords: ribbon synapse, photoreceptor, $\mathrm{Ca}^{2+}$, neurotransmitter release, ion channel

\section{Introduction}

From the initial stages where photoreceptors extract features of the visual scene and through successive and parallel circuits involving retinal interneurons, $\mathrm{Ca}_{\mathrm{v}}$ channels play essential roles at nearly all stages of visual processing. The contributions of $\mathrm{Ca}_{\mathrm{v}}$ channels to the retinal circuitry have largely been explored using pharmacological modulators. However, the availability of genetic models lacking specific $\mathrm{Ca}_{\mathrm{v}}$ channel subtypes, as well as advances in electrophysiological and optical imaging techniques, have 
opened many new avenues for research. In addition, the use of single-cell RNA-seq (scRNA-seq) to illuminate the molecular signature of cell-types in the mouse retina has provided a framework for understanding the expression and function of particular $\mathrm{Ca}_{\mathrm{v}}$ subtypes within the retinal circuitry. In this review, we will consider how $\mathrm{Ca}_{\mathrm{v}}$ channels have taken on unusual properties and functions that appear to be well-tailored for enabling the retina to carry out complex computational tasks, and how mutations affecting $\mathrm{Ca}_{\mathrm{v}}$ channel function may cause vision impairment. Due to space constraints, $\mathrm{Ca}_{\mathrm{v}}$ channels will be discussed in the context of a subset of retinal cell-types. For complementary insights on this topic, the reader is referred to a number of excellent reviews (Pangrsic et al 2018, Van Hook et al 2019).

\subsection{Molecular diversity of $\mathrm{Ca}_{\mathrm{v}}$ channels}

$\mathrm{Ca}_{\mathrm{v}}$ channels were originally classified by their voltage range of activation, with $\mathrm{Ca}_{\mathrm{v}} 1$ and $\mathrm{Ca}_{\mathrm{v}} 2$ channels forming the "high-voltage-activated" channels, and $\mathrm{Ca}_{\mathrm{v}} 3$ channels forming the "low-voltageactivated" channels. Both types of $\mathrm{Ca}_{\mathrm{v}}$ channels are comprised of a pore-forming $\alpha_{1}$ subunit, with $\mathrm{Ca}_{\mathrm{v}} 1$ and $\mathrm{Ca}_{\mathrm{v}} 2$ channels also possessing auxiliary $\beta$ and $\alpha_{2} \delta$ subunits (Fig. 1A). The $\alpha_{1}$ subunit of $\mathrm{Ca}_{\mathrm{v}}$ channels contains 4 homologous repeats, each with 6 transmembrane-spanning $\alpha$-helical domains (S1-S6). Within the S4 segment, a string of positively charged residues plays an important role in voltage-sensing. The S5 and S6 segments contribute to pore-lining regions and are connected by a pore loop containing glutamate residues that determine the high selectivity of $\mathrm{Ca}_{\mathrm{v}}$ channels for $\mathrm{Ca}^{2+}$ ions (Fig.1A). $\mathrm{Ca}_{\mathrm{v}}$ channels were initially named according to the properties of the currents they mediate (e.g., L-type for "long-lasting"). According to current nomenclature, "Ca $a_{v} 1-3 . x$ " describes the channels according to the identity of their $\alpha_{1}$ subunit; "CACNxxx" names the genes encoding the various subunits (Fig.1B).

Given this molecular and functional diversity, knowledge of the expression patterns and subcellular localization of $\mathrm{Ca}_{\mathrm{v}}$ subtypes in the retina is needed to elucidate the roles of $\mathrm{Ca}_{\mathrm{v}}$ channels in visual processing and how they may be derailed in inherited forms of vision loss. However, the current pharmacological modulators do not effectively discriminate between subtypes of $\mathrm{Ca}_{\mathrm{v}} 1$ (e.g., $\mathrm{Ca}_{\mathrm{v}} 1.2$, $\mathrm{Ca}_{\mathrm{v}} 1.3$, and $\mathrm{Ca}_{\mathrm{v}} 1.4$ ) or $\mathrm{Ca}_{\mathrm{v}} 3$ channels (e.g., $\mathrm{Ca}_{\mathrm{v}} 3.1, \mathrm{Ca}_{\mathrm{v}} 3.2, \mathrm{Ca}_{\mathrm{v}} 3.3$ ) (Fig.1B). Moreover, many reports describing the cellular and subcellular localization of $\mathrm{Ca}_{\mathrm{v}}$ channels have relied on immunolabelling with antibodies of undocumented specificity. A promising complementary approach is droplet-based scRNAseq, which allows for analysis of RNA expression in thousands of individual cells at once. This strategy has define, at the molecular level, many known and some newly discovered retinal cell-types. Using one of these scRNA-seq datasets (Macosko et al 2015), we have summarized the expression of Ca $\mathrm{v}_{\mathrm{v}}$ subunits in a subset of retinal cell-types in Figure 2 and will refer to this resource in subsequent sections. 


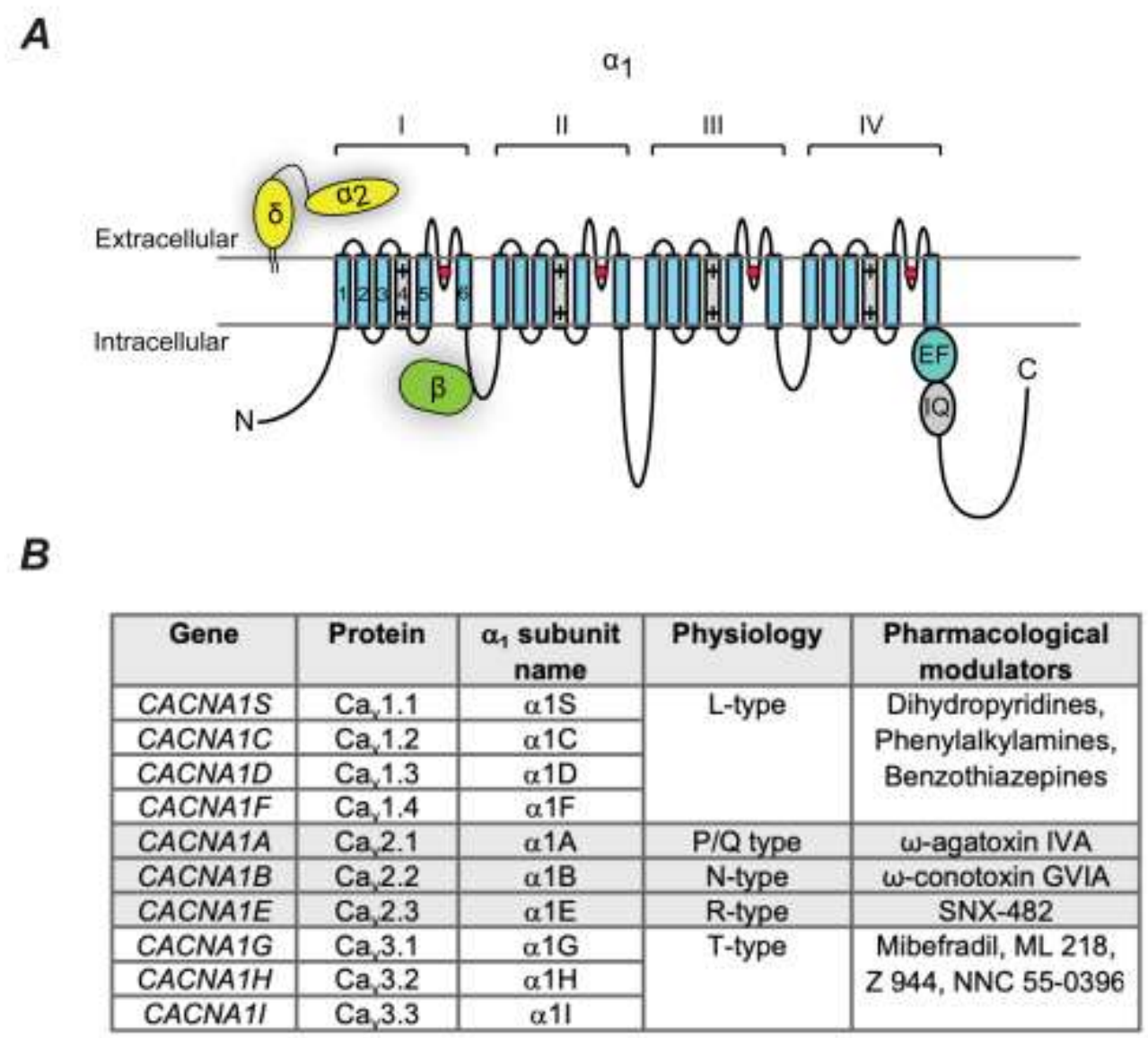

Figure 1. Molecular composition and nomenclature of $\mathrm{Ca}_{\mathrm{v}}$ channels. $A$, The $\mathrm{Ca}_{\mathrm{v}} \alpha_{1}$ subunit is comprised of 4 homologous domains (I-IV), each containing 6 alpha-helical transmembrane-spanning segments (S) (1-6). Positively charged residues (+) within S4 helices are indicated. Extracellular loop linking S5 and S6 form the pore; red circle indicates conserved glutamate in each domain that contributes to the selectivity filter. The C-terminal domain contains an EF-hand and IQ-domain that are important for $\mathrm{Ca}^{2+} / \mathrm{CaM}$-dependent modulation. For $\mathrm{Ca}_{\mathrm{v}} 1$ and $\mathrm{Ca}_{\mathrm{v}} 2$ channels, auxiliary $\beta$ and $\alpha_{2} \delta$ subunits interact with the $\alpha_{1}$ subunit at intracellular and extracellular sites, respectively. $B$, Nomenclature for $\alpha_{1}$ subunits based on names for human genes and protein classification (Ertel et al 2000). Names were initially based on tissue of origin (e.g., $\alpha 1 \mathrm{~S}$ for "skeletal muscle $\alpha_{1}$ subunit") and physiological properties (e.g., T-type for "transient" vs. L-type for "long-lasting”). Major classes of pharmacological modulators are indicated.

\section{1. $\mathrm{Ca}_{\mathrm{v}} 1$ channels}

$\mathrm{Ca}_{\mathrm{v}} 1$ (L-type) channels are distinguished from other $\mathrm{Ca}_{\mathrm{v}}$ channels by their sensitivity to dihydropyridine-based drugs (Fig.1B). In contrast to their primarily postsynaptic functions in most neurons, $\mathrm{Ca}_{\mathrm{v}} 1$ channels often play presynaptic roles in the retina. Of the four $\mathrm{Ca}_{\mathrm{v}} 1$ subtypes, $\mathrm{Ca}_{\mathrm{v}} 1.3$ and $\mathrm{Ca}_{\mathrm{v}} 1.4$ predominate in a number of retinal cell-types such as photoreceptors and bipolar cells (Fig.2A,B). $\mathrm{Ca}_{\mathrm{v}} 1.3$ and $\mathrm{Ca}_{\mathrm{v}} 1.4$ exhibit properties that are well-suited for their exocytotic functions at the specialized "ribbon" synapses formed by these cells, which include rapid activation at relatively negative voltages 
and slow inactivation (Pangrsic et al 2018). $\mathrm{Ca}_{\mathrm{v}} 1$ channels couple electrical activity to changes in gene transcription in many neurons, but whether they do so in retinal neurons remains to be established.

$A$

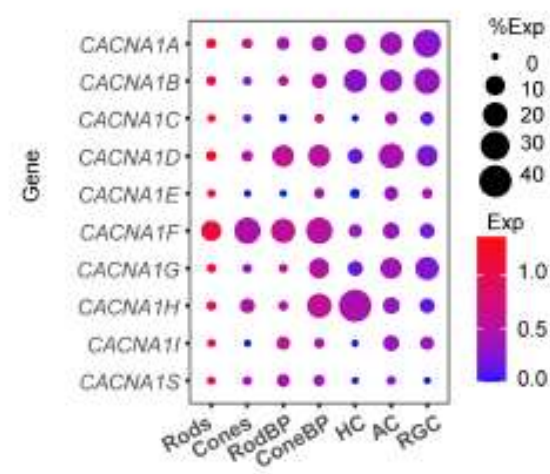

B

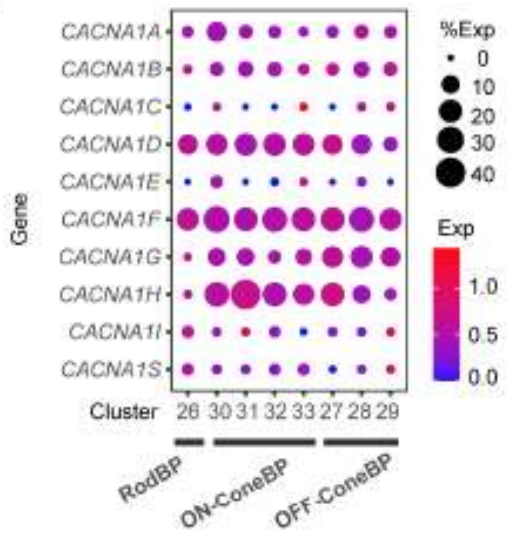

C

D
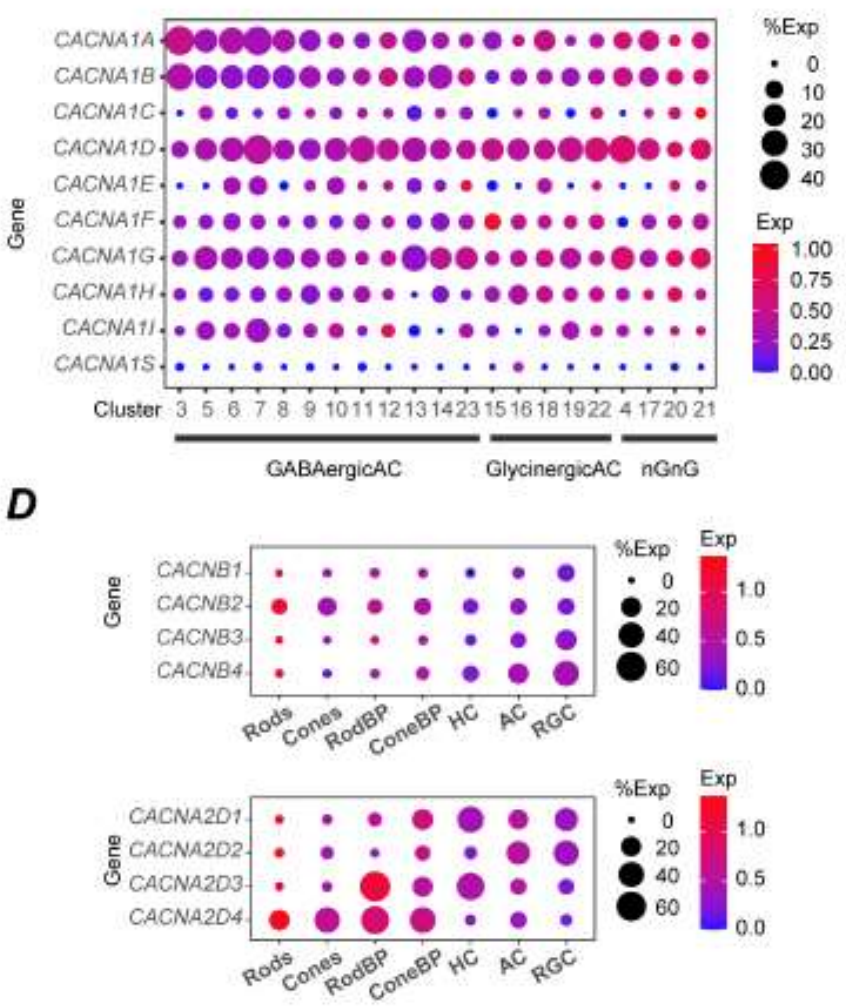

Figure 2. Expression of $\mathrm{Ca}_{\mathrm{v}}$-encoding genes in mouse retinal cell-types. $A-D$, Dot blots illustrating the expression of $\mathrm{Ca}_{\mathrm{v}}$ subtypes corresponding to $\alpha_{1}$ (Cacna1x, $A-C$ ) or $\beta$ (Cacnbx) and $\alpha_{2} \delta$ (Cacna2dx;D) as determined by scRNA-seq. Results are plotted according to cell clusters identified in mouse retina at P14 (Macosko et al 2015). The size and color of the dots reflect the \% of cells in which the transcript was detected and the averaged level of that transcript, respectively. Due to limitations in the sensitivity of the scRNA-seq method, as well as the relatively low expression levels of $\mathrm{Ca}_{v}$ genes, the dot size is generally $<60 \%$. Because the total number of transcripts in rods is less than that for other cell-types, the resulting expression value in rods appears higher than in other cell classes when scaling to the median value across all classes. For example, the expression of $\mathrm{Ca}_{v}$ genes in rods other than Cacna1f, Cacnb2, and Cacna2d4, can be considered as not different from background levels. Plots represent: Cacna1 expression in major retinal cell-types (rods, cones, rod bipolar (BP) cells, cone BP cells, horizontal cells $(H C)$, amacrine cells $(A C)$, and retinal ganglion cells $(R G C)(A)$, specific classes of BP cells $(B)$, and distinct clusters of amacrine cells (GABA-ergic, glycinergic, and non-GABAergic, non-glycinergic, non-glutamatergic ( $\mathrm{nGnG}$ ) (C); and Cacnb1 and Cacna2d expression in the same cell-types as in $A$. In $C$, clusters 3 and 16 exhibit the molecular signature of starburst ACs and All ACs, respectively. 


\section{2. $\mathrm{Ca}_{\mathrm{v}} 2$ channels}

$\omega$-agatoxin IVA, $\omega$-conotoxin GVIA, and SNX-482 are are highly selective blockers of $\mathrm{Ca}_{\mathrm{v}} 2.1$ (P/Q-type), $\mathrm{Ca}_{\mathrm{v}} 2.2$ (N-type), and Ca 2.3 (R-type) channels, respectively (Fig.1B). At many synapses, $\mathrm{Ca}_{\mathrm{v}} 2$ channels regulate fast, phasic neurotransmitter release. Molecular determinants in the $\mathrm{C}$-terminal domain (CTD) of $\mathrm{Ca}_{\mathrm{v}} 2$, which are not conserved in $\mathrm{Ca}_{\mathrm{v}} 1$, have been shown to support the presynaptic localization and function of $\mathrm{Ca}_{\mathrm{v}} 2$ channels (Lubbert et al 2017, Maximov \& Bezprozvanny 2002). By the same token, the absence of key determinants in the $\mathrm{Ca}_{\mathrm{v}} 2 \mathrm{CTD}$ that are present in $\mathrm{Ca}_{\mathrm{v}} 1$ may explain why $\mathrm{Ca}_{\mathrm{v}} 2$ channels are excluded from ribbon synapses. $\mathrm{Ca}_{\mathrm{v}} 2$ channels are most prominently represented in retinal cell-types other than photoreceptors and bipolar cells (Fig.2A-C), where they work in concert with other ion channels in regulating excitability and neurotransmitter release.

\section{3. $\mathrm{Ca}_{\mathrm{v}} 3$ channels}

Originally classified as "low voltage-activated" channels, $\mathrm{Ca}_{\mathrm{v}} 3$ channels activate and inactivate at extremely negative voltages, ( -50 mV and $-30 \mathrm{mV}$, respectively) (Perez-Reyes 2003). Consequently, $\mathrm{Ca}_{\mathrm{v}} 3$ channels are inactivated at voltages near resting potential of most neurons. A period of hyperpolarization permits recovery of these channels from inactivation, and this can trigger rebound burst firing of action potentials (Kim et al 2001). By sc-RNAseq, $\mathrm{Ca}_{\mathrm{v}} 3$ channels are expressed at significant levels in most retinal neurons except rods and rod bipolar cells (Fig.2A-C). Compared to major advances in pinpointing the roles of $\mathrm{Ca}_{\mathrm{v}} 3$ channels in seizure activity and chronic pain (Perez-Reyes 2003), our understanding of how $\mathrm{Ca}_{\mathrm{v}} 3$ channels contribute to retinal function is relatively limited.

\subsection{Auxiliary $\beta$ and $\alpha_{2} \delta$ subunits}

The auxiliary $\beta$ and $\alpha_{2} \delta$ subunits are resident components of $\mathrm{Ca}_{\mathrm{v}} 1$ and $\mathrm{Ca}_{\mathrm{v}} 2$ channel complexes, and critically regulate the biophysical properties, trafficking, and cell-surface expression levels of these channels. The $\beta$ subunits $\left(\beta_{1}-\beta_{4}\right)$ bind to a site in the cytoplasmic loop connecting domains II and III of the $\alpha_{1}$ subunit of $\mathrm{Ca}_{\mathrm{v}} 1$ and $\mathrm{Ca}_{\mathrm{v}} 2$ channels (Fig.1A). In general, $\beta$ subunits increase the amplitude of the $\mathrm{Ca}^{2+}$ currents $\left(I_{C a}\right)$ mediated by $\mathrm{Ca}_{\mathrm{v}} 1$ and $\mathrm{Ca}_{\mathrm{v}} 2$ channels due to a higher density of channels in the plasma membrane, an increase in channel open probability, and/or a hyperpolarizing shift in the voltagedependence of channel activation (Buraei \& Yang 2013). The interaction with $\beta$ protects the $\alpha_{1}$ subunit from ubiquitin-dependent proteosomal degradation, thus enhancing the cell-surface levels of $\mathrm{Ca}_{\mathrm{v}} 1$ and $\mathrm{Ca}_{\mathrm{v}} 2$ channels (Altier et al 2011, Waithe et al 2011). $\beta$ subunits can also have $\mathrm{Ca}_{\mathrm{v}}$ independent functions. For example, $\beta_{4}$ undergoes activity-dependent translocation to the nucleus and regulates gene transcription through interactions with nuclear proteins rather than with the $\mathrm{Ca}_{\mathrm{v}}$ channel complex (Subramanyam et al 2009, Tadmouri et al 2012).

$\alpha_{2} \delta$ subunits ( $\left.\alpha_{2} \delta-1-4\right)$ are comprised of two polypeptides, $\alpha_{2}$ and $\delta$, which are encoded by the same gene. The $\alpha_{2} \delta$ pre-protein is proteolytically processed into $\alpha_{2}$ and $\delta$ which remain bound together by a disulfide linkage. The mature $\alpha_{2} \delta$ protein is attached to the plasma membrane via a glycosylphosphatidylinositol anchor (Dolphin 2013) (Fig.1A). The most prominent effect of $\alpha_{2} \delta$ is to increase the cell-surface levels of $\mathrm{Ca}_{\mathrm{v}} 1$ and $\mathrm{Ca}_{\mathrm{v}} 2$ channels in a manner that requires the presence of $\mathrm{Ca}_{\mathrm{v}} \beta$ (Cassidy et al 2014). While in complex with presynaptic $\mathrm{Ca}_{\mathrm{v}}$ channels, or possibly independently, $\alpha_{2} \delta$ may engage in trans-synaptic interactions with proteins that regulate synapse formation and/or stability (Fell et al 2016, Geisler et al 2019, Wang et al 2017).

As is the case in many neurons, most retinal neurons express multiple subtypes of $\beta$ and $\alpha_{2} \delta$ (Fig.2D) that differ in terms of their regulation of $\mathrm{Ca}_{\mathrm{v}}$ channels as well as their non-canonical functions 
(Dolphin 2016). Studies of the corresponding KO mice would help dissect the retinal functions of specific $\beta$ and $\alpha_{2} \delta$ subtypes. However, retinal phenotypes have thus far been described only for mice lacking expression of $\beta_{2}$ or $\alpha_{2} \delta-4$ (Ball et al 2002, Katiyar et al 2015, Kerov et al 2018, Wang et al 2017, Wycisk et al 2006a).

3. $\mathrm{Ca}_{\mathrm{v}}$ channels are differentially expressed in retinal cell-types

Vision begins with the conversion of light into electrical signals by rod and cone photoreceptors, a process that modulates the release of glutamate from their synaptic terminals. The resulting signal is shaped via the activity of horizontal cells, bipolar cells, and amacrine cells prior to integration by the retinal ganglion cells (RGCs) and transmission into higher-order brain regions via RGC axons in the optic nerve (Fig.3A). Within the retinal circuitry, $\mathrm{Ca}_{\mathrm{v}}$ channels are functionally specialized and often discretely localized in order to ensure the proper encoding of visual information.

\subsection{Rod and cone photoreceptors}

The somata of rods and cones lie in the outer nuclear layer (ONL) of the retina and extend axons into the outer plexiform layer (OPL) where they form synapses with bipolar and horizontal cells (Fig. 3A). The terminals of rods (spherules) and cones (pedicles) are characterized by synaptic ribbons that tether and replenish thousands of glutamate-filled synaptic vesicles near the specialized release sites (i.e., active zones) (Matthews \& Fuchs 2010). Within these terminals, the opening of $\mathrm{Ca}_{\mathrm{v}}$ channels at the depolarized membrane potential of photoreceptors in darkness permits tonic, $\mathrm{Ca}^{2+}$-dependent exocytosis of glutamate into the synaptic cleft. Light-dependent hyperpolarization of the photoreceptor membrane decreases $\mathrm{Ca}_{\mathrm{v}^{-}}$ mediated $\mathrm{Ca}^{2+}$ influx, thereby suppressing glutamate release (Choi et al 2008, Copenhagen \& Jahr 1989, Johnson et al 2007). The decline in synaptic glutamate depolarizes ON bipolar cells and hyperpolarizes OFF bipolar cells by diminishing ligand activation of metabotropic mGluR6 receptors and ionotropic AMPA or kainate receptors, respectively (Connaughton 1995). Based on its sensitivity to dihydropyridinebased drugs (Fig.1B), the $\mathrm{Ca}_{\mathrm{v}}$ channel that regulates glutamate release by photoreceptors was classified as the $\mathrm{Ca}_{\mathrm{v}} 1$ subtype (Barnes \& Hille 1989, Corey et al 1984, Schmitz \& Witkovsky 1997, Taylor \& Morgans 1998).

\subsection{1. $\mathrm{Ca}_{\mathrm{v}} 1.4$ regulates the maturation and function of rod and cone synapses}

Large-scale sequencing of a genetic locus for the X-linked form of congenital stationary night blindness (CSNB2) revealed causative mutations in CACNA1F-the gene that is now recognized to encode Cav1.4 (Bech-Hansen et al 1998, Strom et al 1998). A common feature of the electroretinograms (ERGs) of CSNB2 patients is that $b$-waves representing transmission from photoreceptors to second-order neurons are significantly reduced while a-waves resulting from light-dependent hyperpolarization of photoreceptors are minimally altered (Zeitz et al 2015). Loss-of-function and null mutations in Cacna1f cause similar ERG phenotypes in various mouse strains (Chang et al 2006, Mansergh et al 2005, Regus-Leidig et al 2014) and visual behavior defects in zebrafish (Jia et al 2014).

Among Cav-encoding genes, Cacna1f is the most prominently expressed in rods and cones in mouse retina (Fig.2A-C). A role for $\mathrm{Ca}_{v} 1.4$ in mediating presynaptic $\mathrm{Ca}^{2+}$ signals in mouse photoreceptors is further supported by the near elimination of depolarization-evoked $\mathrm{Ca}^{2+}$ transients in the OPL (Mansergh et al 2005, Regus-Leidig et al 2014) and the lack of rod $I_{C a}$ in Cav1.4 knockout (KO) mice (Maddox et al 2020). Cav1.4 protein is tightly clustered along the 
base of the synaptic ribbon in rods and cones (Liu et al 2013b, Morgans 2001, Specht et al 2009), and thus is well-positioned to regulate the exocytosis of glutamate.

A notable aspect of the retina of Cav1.4 KO mice is the complete absence of rod and cone synapses in the OPL (Liu et al 2013b, Zabouri \& Haverkamp 2013). Rod and cone synaptogenesis occurs postnatally and involves the formation of elongated ribbons, the coalescence of presynaptic and postsynaptic signaling complexes (Fig.3B), and the invagination into the pedicle or spherule of neurites emanating from two horizontal cells and one ON bipolar cell (Blanks et al 1974, Regus-Leidig et al 2009). The OPL of Cav1.4 KO mice is devoid of ribbons; bipolar and horizontal cell neurites sprout from the OPL into the ONL of these mice, perhaps due to the absence of presynaptic input (Liu et al 2013b, Raven et al 2008, RegusLeidig et al 2014, Zabouri \& Haverkamp 2013) (Fig.3C). The lack of mature rod and cone synapses in Cav1.4 KO mice at any time during postnatal development suggests that Cav1.4 is essential for photoreceptor synaptogenesis (Liu et al 2013b, Zabouri \& Haverkamp 2013).

Cav1.4 could mediate $\mathrm{Ca}^{2+}$-dependent processes, such as neurotransmitter release, which are required for rod and cone synapse formation. An alternative, but not mutually exclusive, possibility is that Cav1.4 could interact with key scaffolding and other synapseassociated proteins needed to initiate synapse assembly (Fig.3B). To distinguish between these possibilities, our group analyzed rod synapses of mice expressing a non-conducting mutant form of Cav1.4 (G369i). Unlike in Cav1.4 KO mice, ribbons and pre- and post-synaptic proteins are present in rods of G369i knock-in mice. Rod bipolar and horizontal cell neurites appose mature spherules in the OPL and ectopically in the ONL, but fail to invaginate into the spherules (Fig.3C) (Maddox et al 2020). Although the cone phenotype of the G369i mice is still under investigation, these results suggest that while dispensable for the molecular organization of rod synapses, Cav1.4 $\mathrm{Ca}^{2+}$ influx is required for their structural maturity and localization in the OPL.

\subsubsection{Cav1.3}

A number of studies have reported the expression of Cacnald, which encodes $\mathrm{Ca}_{\mathrm{v}} 1.3$, in photoreceptors of mouse retina by in situ hybridization (Xiao et al 2007) and antibody labelling (Kersten et al). However, scRNA-seq analyses suggest very low representation of Cacnald compared to Cacnalf in rods and cones in mouse retina (Macosko et al 2015) (Fig.2A). In addition, Ca $1.3 \mathrm{KO}$ mice exhibit relatively mild retinal phenotypes compared to those of $\mathrm{Ca}_{\mathrm{v}} 1.4 \mathrm{KO}$ mice including no significant alterations in ERG b-waves (Busquet et al 2010, Wu et al 2007) but see (Shi et al 2017)). Abnormal ribbon morphology and a reduced density of ribbon synapses was found in the OPL of $\mathrm{Ca}_{\mathrm{v}} 1.3 \mathrm{KO}$ retina (Busquet et al 2010, Shi et al 2017), which could result from loss of expression of $\mathrm{Ca}_{\mathrm{v}} 1.3$ in cell-types other than photoreceptors. For example, Cacnald is expressed in horizontal cells (Fig.2A) which are required for optimal photoreceptor synapse development (Soto et al 2013). Taken together, the current evidence favors $\mathrm{Ca}_{\mathrm{v}} 1.4$ as the major $\mathrm{Ca}_{\mathrm{v}} 1$ subtype that is expressed in rods and cones and which is indispensable for photoreceptor synapse assembly and transmission in the mouse retina.

\subsubsection{Auxiliary $\beta_{2}$ and $\alpha_{2} \delta-4$ subunits are required for rod and cone synaptic transmission}

Of all the $\beta$ and $\alpha_{2} \delta$ subtypes, $\beta_{2}$ and $\alpha_{2} \delta-4$ are most prominently expressed among rods and cones (Fig.2D), and likely to be involved in regulating $\mathrm{Ca}_{\mathrm{v}} 1.4$ in these cells based on multiple lines of evidence. First, mice lacking expression of $\beta_{2}$ or $\alpha_{2} \delta-4$ exhibit ERG defects indicative of weakened rod and cone transmission (Ball et al 2002, Katiyar et al 2015, Kerov et al 2018, Wang et al 2017). Second, levels of $\mathrm{Ca}_{\mathrm{v}} 1.4$ protein in the OPL are severely reduced in $\beta_{2} \mathrm{KO}$ and $\alpha_{2} \delta-4 \mathrm{KO}$ mice (Ball et al 2002, Katiyar et 
al 2015, Kerov et al 2018, Wang et al 2017), consistent with a role for these auxiliary subunits in trafficking $\mathrm{Ca}_{\mathrm{v}}$ channels to the cell-surface (Buraei \& Yang 2013, Dolphin 2013). Third, $\beta_{2}$ and $\alpha_{2} \delta-4$ interact with $\mathrm{Ca}_{\mathrm{v}} 1.4$ in mouse retina based on co-immunoprecipitation and proximity ligation assays (Lee et al 2015).

As is the case in $\mathrm{Ca}_{\mathrm{v}} 1.4 \mathrm{KO}$ mice, rod spherules of $\beta_{2} \mathrm{KO}$ (Ball et al 2002, Katiyar et al 2015) and $\alpha_{2} \delta-4$ KO mice (Fig.3C) (Kerov et al 2018, Wang et al 2017) lack ribbons and do not form synaptic specializations with bipolar and horizontal cells. This result is not surprising given the reduced density of $\mathrm{Ca}_{\mathrm{v}} 1.4$ protein in the OPL of both KO mouse strains (Ball et al 2002, Katiyar et al 2015, Kerov et al 2018, Wang et al 2017). Curiously, synaptic ribbons are spared in cone pedicles of $\beta_{2} \mathrm{KO}$ and $\alpha_{2} \delta-4 \mathrm{KO}$ mice (Fig.3C) (Katiyar et al 2015, Kerov et al 2018, Wang et al 2017). Perhaps the expression of other $\beta$ and $\alpha_{2} \delta$ subtypes in cones, albeit low (Fig.2D), is sufficient to traffic enough $\mathrm{Ca}_{\mathrm{v}} 1.4$ to support ribbon formation in pedicles of $\beta_{2} \mathrm{KO}$ and $\alpha_{2} \delta-4 \mathrm{KO}$ mice.

$\alpha_{2} \delta-4$ has been implicated in the functions of ELFN1, a cell-adhesion molecule that is expressed in rods (Cao et al 2015). It has been proposed that cis interactions between $\alpha_{2} \delta-4$ and ELFN1 in rods enable a trans interaction of ELFN1 and mGluR6 (Fig.3B) needed to organize postsynaptic signaling complexes in, and enable synaptic contacts with, rod bipolar cells (Wang et al 2017). In support of this possibility, $\alpha_{2} \delta-4$ co-immunoprecipitates with ELFN1 when co-transfected in HEK293 cells, and this is disrupted by deletion of the distal part of the ELFN1 ectodomain. However, the isolated ELFN1 ectodomain did not interact with $\alpha_{2} \delta-4$ in pull-down assays, and the prediction that $\alpha_{2} \delta-4$ lacking the putative ELFN1 binding sequence should rescue rod synaptogenesis in $\alpha_{2} \delta-4 \mathrm{KO}$ mice could not be tested since the mutant $\alpha_{2} \delta-4$ protein could not be expressed in rods of these mice (Wang et al 2017). Given previous findings that co-immunoprecipitation of $\alpha_{2} \delta$ proteins in heterologous expression systems can be highly non-specific (Brockhaus et al 2018), and may not accurately reflect protein interactions of $\alpha_{2} \delta$ at the cell surface (Lana et al 2016), the significance of the interaction of $\alpha_{2} \delta-4$ and ELFN1 for rod to rodbipolar connectivity warrants further study.

Despite the normalcy of cone ribbons in $\alpha_{2} \delta-4 \mathrm{KO}$ mice, serial block face scanning electron microscopy revealed that cone pedicles lack triadic structure in these mice, most likely due to a failure of postsynaptic horizontal and bipolar neurites to invaginate (Kerov et al 2018)(Fig.3C). Whether resulting from abnormal cone synapse formation and/or maintenance, these structural abnormalities could contribute to the severe defects in cone transmission in $\alpha_{2} \delta-4 \mathrm{KO}$ mice (Kerov et al 2018, Wang et al 2017) as well as in humans affected by mutations in the gene encoding $\alpha_{2} \delta-4$ (CACNA2D4) (Ba-Abbad et al 2015, Wycisk et al 2006b). 

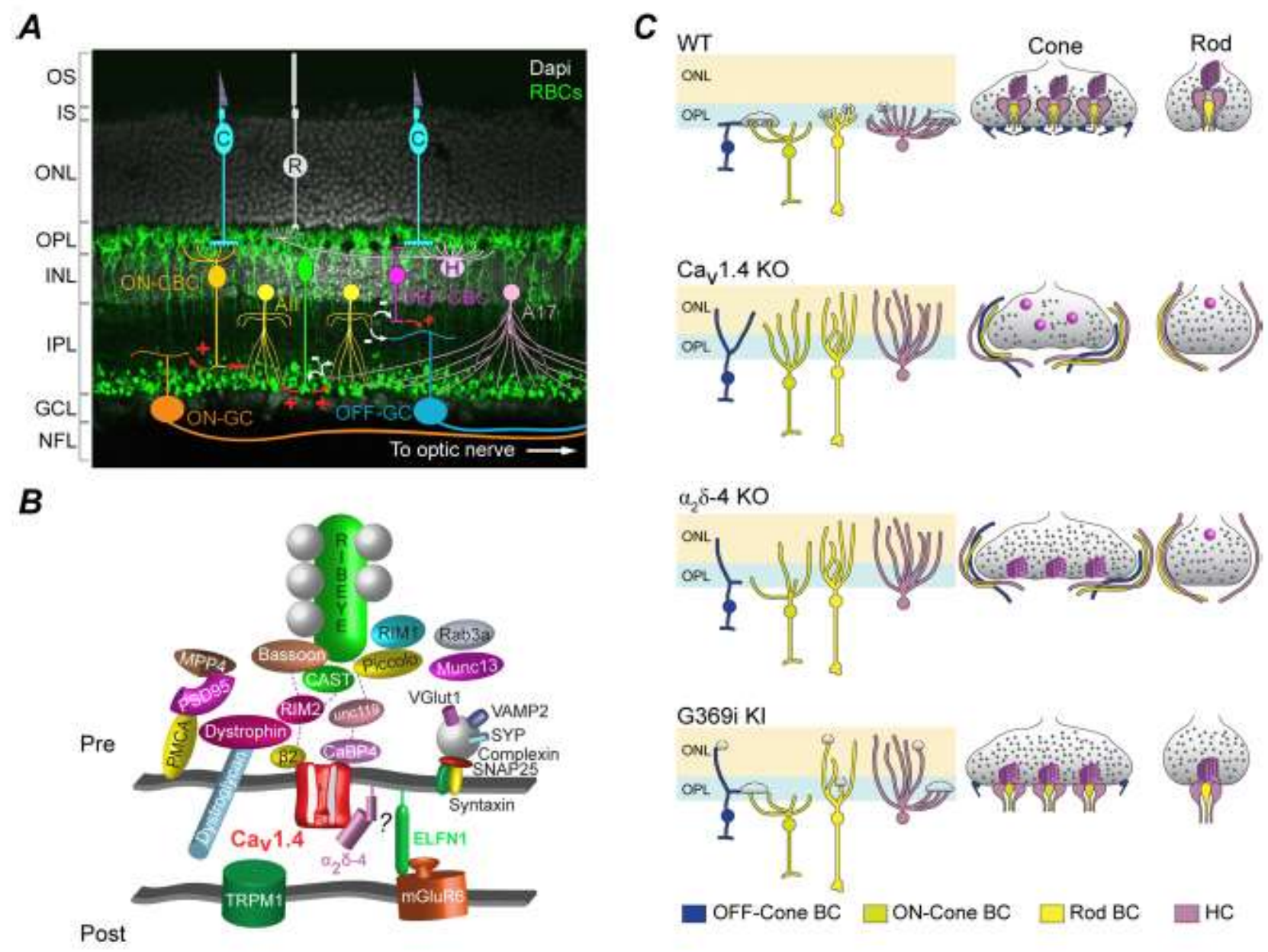

Figure 3. Cav1.4 channels at photoreceptor synapses. $A$, Cross-section of mouse retina labeled with Dapi and antibodies against protein kinase $\mathrm{C}$ to mark nuclei and rod bipolar cells (RBCs), respectively. Overlaid is a schematic showing retinal cell-types and their patterns of connectivity. Outer segment (OS), inner segment (IS), outer nuclear layer (ONL), outer plexiform layer (OPL), inner nuclear layer (INL), inner plexiform layer (IPL), ganglion cell layers (GCL), nerve fiber layer (NFL), rod (R) and cone (C) photoreceptors, cone bipolar cells (CBC), retinal ganglion cells (GC), horizontal cells (H), and RBCs (green). '+' and '-' indicate excitatory and inhibitory inputs, respectively. Zig-zag line represents gap junction connections. $B$, Schematic of a rod synapse showing relationships of $\mathrm{Ca}_{\mathrm{v}} 1.4$ with synapseassociated proteins. Dotted lines indicate putative direct or indirect interactions of $\mathrm{Ca}_{\mathrm{v}} 1.4$ with other synaptic proteins. $C$, Schematic illustrating morphology of WT photoreceptor synapses and defects reported in $\mathrm{Ca}_{\mathrm{v}} 1.4 \mathrm{KO}, \alpha_{2} \delta-4 \mathrm{KO}$, and G369i knock-in mouse retina. Modified from (Maddox et al 2020).

\subsection{Bipolar cells}

Rod (ON) bipolar cells and cone (ON and OFF) bipolar cells receive inputs from rods and cones, respectively, and form glutamatergic ribbon synapses in the inner plexiform layer (IPL) with various partners (Fig.3A). Cone bipolar cells are functionally heterogeneous and release glutamate directly onto the dendrites of RGCs whereas rod bipolar cells form synapses with AII amacrine cells that innervate 
distinct types of cone bipolar cells and RGCs (Euler et al 2014) (Fig.3A). As is the case at photoreceptor synapses, $\mathrm{Ca}_{\mathrm{v}} 1$ is the primary $\mathrm{Ca}_{\mathrm{v}}$ subtype that regulates transmission at bipolar ribbon synapses. Although their physiological significance is not entirely clear, $\mathrm{Ca}_{\mathrm{v}} 2$ and $\mathrm{Ca}_{\mathrm{v}} 3$ subtypes are also present to varying degrees in the different classes of cone bipolar cells (Fig.2A,B).

\subsection{1. $\mathrm{Ca}_{\mathrm{v}} 1$ channels regulate bipolar cell synaptic transmission}

Dihydropyridine analogs were used to show that $\mathrm{Ca}_{\mathrm{v}} 1$ channels mediate presynaptic $I_{C a}$ and glutamate release from retinal bipolar cells in rats (Hartveit 1999, Pan 2000, Pan 2001, Protti \& Llano 1998) and mice (Satoh et al 1998). In mouse retina, $\mathrm{Ca}_{\mathrm{v}} 1.4$ and $\mathrm{Ca}_{\mathrm{v}} 1.3$ are the major $\mathrm{Ca}_{\mathrm{v}} 1$ subtypes in most rod and cone bipolar cell-types (Macosko et al 2015) (Fig.2A,B). The compensating effect of either $\mathrm{Ca}_{\mathrm{v}} 1$ subtype could explain why depolarization-evoked $\mathrm{Ca}^{2+}$ signals are not diminished in the IPL of $\mathrm{Ca}_{\mathrm{v}} 1.4 \mathrm{KO}$ mice (Mansergh et al 2005), and that $\mathrm{Ca}_{\mathrm{v}} 1.3 \mathrm{KO}$ mice do not show signs of disrupted bipolar cell transmission (Busquet et al 2010).

\subsection{2. $\mathrm{Ca}_{\mathrm{v}} 2$ and $\mathrm{Ca}_{\mathrm{v}} 3$ channels are also expressed in bipolar cells}

Based on their unique biophysical properties, $\mathrm{Ca}_{\mathrm{v}} 3$ channels have also been detected in electrophysiological recordings of various bipolar cell-types (Hartveit 1999, Pan 2000, Pan 2001, Singer \& Diamond 2003). mRNAs corresponding to $\mathrm{Ca}_{\mathrm{v}} 3.1$ and $\mathrm{Ca}_{\mathrm{v}} 3.2$ are particularly well-represented in some classes of cone bipolar cells in mouse retina (Macosko et al 2015, Shekhar et al 2016) (Fig.2A,B). In both cone and rod bipolar cells, the transient $\mathrm{Ca}^{2+}$ current $\left(\right.$ Irans, $\left._{\mathrm{Ca}}\right)$ mediated by $\mathrm{Ca}_{\mathrm{v}} 3$ is $\sim 4$ times larger than that of the $\mathrm{Ca}_{\mathrm{v}} 1$-mediated sustained component and contributes significantly to synaptic glutamate release when $\mathrm{Ca}_{\mathrm{v}} 3$ inactivation is removed by negative voltages (Cui et al 2012, Pan et al 2001, Singer \& Diamond 2003). Although $\mathrm{Ca}_{\mathrm{v}} 3$ channels will generally be inactivated at the resting voltage of bipolar cells $(\sim-40$ to $-50 \mathrm{mV}$ ) (Euler \& Masland 2000), bipolar cell terminals receive significant inhibitory feedback from amacrine cells (Eggers \& Lukasiewicz 2011). Hyperpolarization resulting from such feedback could relieve inactivation of $\mathrm{Ca}_{\mathrm{v}} 3$ channels, thus priming $\mathrm{Ca}_{\mathrm{v}} 3$ channels for opening in ways that could augment glutamate release at bipolar synapses.

At first glance, the near complete blockade of the sustained component of $I_{C a}$ in bipolar cells by $\mathrm{Ca}_{\mathrm{v}} 1$ blockers (Hartveit 1999, Pan 2000, Pan 2001, Protti \& Llano 1998, Satoh et al 1998) suggests that $\mathrm{Ca}_{\mathrm{v}} 2$ channels contribute little to $I_{C a}$ in these cells. However, Cacnala and Cacnalb, which encode Ca 2.1 and $\mathrm{Ca}_{\mathrm{v}} 2.2$, respectively, are moderately expressed in mouse $\mathrm{ON}$ and OFF cone bipolar cells (Fig.2B). Compared to $\mathrm{Ca}_{\mathrm{v}} 1$ channels, $\mathrm{Ca}_{\mathrm{v}} 2$ channels undergo robust modulation by heterotrimeric G-proteins and $\mathrm{Ca}^{2+}$ which underlies short-term synaptic plasticity at non-retinal synapses (Dolphin \& Lee 2020). The use of specific fluorescent reporter lines for bipolar cells (Lu et al 2013) could aid in resolving whether $\mathrm{Ca}_{\mathrm{v}} 2$ channels similarly contribute to synaptic transmission in ways that could be used to distinguish between cone bipolar cell types.

\subsection{Horizontal cells express $\mathrm{Ca}_{\mathrm{v}} 1, \mathrm{Ca}_{\mathrm{v}} 2$, and $\mathrm{Ca}_{\mathrm{v}} 3$ channels}

Horizontal cells are interneurons that typically respond with graded changes in membrane potential in response to glutamatergic input from photoreceptors (Baylor et al 1971, Kolb 1995b). The primary function of horizontal cells is to mediate lateral inhibition of photoreceptor output, which is critical for shaping the receptive field properties of bipolar cells needed for contrast sensitivity and color discrimination. In all species, there is one horizontal cell-type that forms synaptic contacts with cones and rods via somatodendritic neurites and a laterally extending axon, respectively (Kolb 1995a) (Fig.3A). Each horizontal cell receives synaptic input from numerous rods and cones, and produces a feedback (surround) inhibition that suppresses photoreceptor output or a feedforward inhibition to bipolar cells (Diamond 
2017). The mechanism underlying feedback regulation involves inhibition of photoreceptor $\mathrm{Ca}_{\mathrm{v}} 1$ channels and may involve GABA release or proton efflux from horizontal cells, or an ephaptic signal caused by changes in the extracellular resistance within the synaptic cleft (Kramer \& Davenport 2015).

Pharmacological evidence supports the existence of $\mathrm{Ca}_{\mathrm{v}} 1, \mathrm{Ca}_{\mathrm{v}} 2$, and $\mathrm{Ca}_{\mathrm{v}} 3$ channels in horizontal cells (Feigenspan et al 2020, Liu et al 2013a, Pfeiffer-Linn \& Lasater 1996, Picaud et al 1998, Schubert et al 2006, Ueda et al 1992). $\mathrm{Ca}_{\mathrm{v}} 1$ channels support spontaneous action potentials in dissociated goldfish horizontal cells (Country et al 2019), but whether this occurs in the intact mammalian retina is less clear. In rat retina, blockade of $\mathrm{Ca}_{\mathrm{v}} 2$ channels $\left(\mathrm{Ca}_{\mathrm{v}} 2.1\right.$ and $\left.\mathrm{Ca}_{\mathrm{v}} 2.2\right)$ but not $\mathrm{Ca}_{\mathrm{v}} 1$ channels increases $\mathrm{Ca}^{2+}$ signals in rods presumably by relieving inhibitory feedback from horizontal cells (Liu et al 2013a). Consistent with prominent levels of $\mathrm{Ca}_{\mathrm{v}} 2.1$ and $\mathrm{Ca}_{\mathrm{v}} 2.2$ mRNA (Cacnala and Cacnalb, respectively) in mouse horizontal cells (Fig.2A), the corresponding antibodies labeled puncta the tips of horizontal cell neurites (Liu et al 2013a). $\mathrm{Ca}_{\mathrm{v}} 2.1$ and $\mathrm{Ca}_{\mathrm{v}} 2.2$ have opposing actions in regulating release at GABA-ergic synapses (Yamamoto \& Kobayashi 2018). Thus, the two $\mathrm{Ca}_{\mathrm{v}} 2$ subtypes could differentially regulate GABA release from horizontal cells in ways that fine-tune feedback regulation of photoreceptors over a broad range of light levels.

Although $\mathrm{Ca}_{\mathrm{v}} 3$ channels were undetected in initial studies (Liu et al 2013a, Schubert et al 2006), $\mathrm{Ca}_{\mathrm{v}} 3.2$ mRNA is particularly high in mouse horizontal cells (Fig.2A). ML218, a specific blocker of Ca 3 channels (Fig.1B), hyperpolarized the membrane and inhibited light responses of adult mouse horizontal cells in retinal slice preparations (Feigenspan et al 2020). $\mathrm{Ca}_{\mathrm{v}} 3$-mediated currents undergo a $\sim 50 \%$ decline in horizontal cells during the period before and after eye-opening in mice (P12-P13) (Feigenspan et al 2020). Based on studies of $\mathrm{Ca}_{\mathrm{v}} 1.4 \mathrm{KO}$ and transgenic coneless mice, it has been proposed that pre-visual signaling between cones and horizontal cells drives the maturation of the latter's dendritic branching and terminal cluster formation (Raven et al 2008, Reese et al 2005). A high density of $\mathrm{Ca}_{\mathrm{v}} 3$ channels could facilitate these morphological changes in horizontal cells, as pathological upregulation of $\mathrm{Ca}_{\mathrm{v}} 3$ channels is linked to alterations in dendritic branching in some neurons (Niesen \& Ge 1999). In the mature retina, $\mathrm{Ca}_{\mathrm{v}} 3$ channels could contribute to pathological forms of activity in horizontal cells. For example, retinal remodeling in rd1 mice that occurs as a consequence of photoreceptor degeneration causes spontaneous oscillatory activity in horizontal cells (Haq et al 2014). Considering that they suppress rhythmic oscillations associated with seizures (Cheong \& Shin 2014), $\mathrm{Ca}_{\mathrm{v}} 3$ blockers may prove useful therapeutically in blunting abnormal retinal activity that could underlie visual symptoms of photoreceptor degeneration in retitinitis pigmentosa (Marc et al 2007).

\subsection{Amacrine cells}

Of the more than 60 types of amacrine cells that have been identified (Yan et al 2020), most modify information flow from bipolar cells to RGCs via electrical coupling and/or glycinergic or GABA-ergic synapses with bipolar cells, RGCs, and other amacrine cells. These diverse connections negotiate complex inhibitory feedback loops that are crucial for inner retinal computations such as those underlying direction selectivity (Wei 2018). Amacrine cells are broadly characterized according to dendritic morphology and lamination within the IPL. Narrow-field amacrine cells have compact dendritic arbors $(<125 \mu \mathrm{m})$ and stratify in multiple layers of the IPL whereas wide-field amacrine cells have expansive dendritic arbors $(>400 \mu \mathrm{m})$ and laminate mainly within one or a few layers of the IPL (Kolb 1995c). The neurites of amacrine cells are specialized for postsynaptic responses and/or presynaptic neurotransmitter release, and often engage in lateral, serial, and reciprocal synapses some of which involve $\mathrm{Ca}_{\mathrm{v}}$ channels. 
3.5.1 AII amacrine cells utilize $\mathrm{Ca}_{\mathrm{v}} 1$ channels for sustained glycinergic transmission in scotopic vision

Narrow-field AII amacrine cells bifurcate the signal received from rod bipolar cells into ON and OFF pathways via gap junctions on their distal, arboreal dendrites with ON cone bipolar cells, and glycinergic synapses formed between their proximal, lobular appendages with OFF cone bipolar cells or OFF RGCs (Famiglietti \& Kolb 1975, Mills \& Massey 1991) (Fig.3A). In mouse AII cells, Ca $a_{v}$ currents activate at relatively negative voltages and are sensitive to dihydropyridine antagonists (Balakrishnan et al 2015, Habermann et al 2003). These features are characteristic of $\mathrm{Ca}_{\mathrm{v}} 1.3$, which was detected in these cells by RT-PCR and scRNA-seq (Habermann et al 2003, Yan et al 2020) (Fig.2C). Ca 1 -mediated Ca ${ }^{2+}$ signals were found in the lobular appendages of AII cells (Habermann et al 2003), and associated with sustained exocytosis that is more typical of ribbon-type synapses than of synapses with purely phasic release properties (Balakrishnan et al 2015). Depolarization-dependent $\mathrm{Ca}^{2+}$ signals were rarely observed in the arboreal dendrites of AII cells (Habermann et al 2003), suggesting that $\mathrm{Ca}_{\mathrm{v}} 1.3$ may be trafficked specifically to glycinergic release sites.

\subsubsection{Interplay between big $\mathrm{K}^{+}(\mathrm{BK})$ channels and $\mathrm{Ca}_{\mathrm{v}} 1$ channels in $\mathrm{A} 17$ amacrine cells $(\mathrm{ACs})$}

Wide-field A17 cells form hundreds of varicosities along their dendrites, which participate in complex inhibitory microcircuits acting in parallel through reciprocal GABAergic synapses with a rod bipolar terminal (Grimes et al 2010, Kolb 1995c). $\mathrm{Ca}_{\mathrm{v}} 1$ seems to be the predominant $\mathrm{Ca}_{\mathrm{v}}$ channel expressed in mouse A17 ACs (Chavez et al 2006, Grimes et al 2009), but its role in neurotransmitter release is more complex than in AII ACs. Despite the prominent contribution of $\mathrm{Ca}_{\mathrm{v}} 1$ to depolarizationevoked $I_{C a}$ recorded in the soma and $\mathrm{Ca}^{2+}$ signals recorded in the varicosities of A17 ACs (Grimes et al 2009), synaptically evoked GABA release from A17 ACs is mediated by $\mathrm{Ca}^{2+}$-permeable AMPA receptors (CP-AMPARs) rather than $\mathrm{Ca}_{\mathrm{v}} 1$ channels (Chavez et al 2006). $\mathrm{BK} \mathrm{Ca}^{2+}$ activated $\mathrm{K}^{+}$channels, which are functionally coupled to $\mathrm{Ca}_{\mathrm{v}} 1$ within $\mathrm{A} 17 \mathrm{AC}$ varicosities, suppress synaptic depolarizations and limit the recruitment of $\mathrm{Ca}_{\mathrm{v}} 1$ channels (Grimes et al 2009). Under low light levels, BK-mediated suppression of $\mathrm{Ca}_{\mathrm{v}} 1$ activation would restrict the amplitude and spread of synaptic depolarizations, thus enhancing feedforward excitatory transmission by rod bipolar cells. Stronger synaptic stimulation of A17 AC varicosities with increasing light intensities is expected to inactivate BK channels, which would enable $\mathrm{Ca}_{\mathrm{v}} 1$-dependent contributions to GABA release, thereby expanding the boundaries of surround feedback inhibition (Grimes et al 2009). Ca 1.3 was found to co-immunoprecipitate with BK channels from rat retinal lysates (Grimes et al 2015), suggesting close proximity of these channels within A17 ACs and/or other retinal cell-types. $\mathrm{Ca}_{\mathrm{v}} 1.3$ interacts with a variety of PDZ-domain containing scaffolding proteins that regulate the clustering of these channels within discrete microdomains (Gregory et al 2011, Jenkins et al 2010, Olson et al 2005). Such protein interactions could ensure compartmentalized signaling by macromolecular complexes of $\mathrm{BK}, \mathrm{Ca}_{\mathrm{v}} 1.3$, and potentially other regulatory molecules within A17 varicosities.

While the profile of A17 cells could not be definitively assigned based on scRNA-seq analysis, most GABA-ergic ACs are characterized by the expression of multiple $\mathrm{Ca}_{\mathrm{v}}$ subtypes including $\mathrm{Ca}_{\mathrm{v}} 1.3$ and $\mathrm{Ca}_{\mathrm{v}} 3$ channels (Fig.2C) (Yan et al 2020). Although $\mathrm{Ca}_{\mathrm{v}} 3$ channels are often involved in forms of dendritic integration that would run counter to the functional compartmentalization of A17 dendrites (Grimes et al 2015), these channels could play presynaptic roles. For example, at some cortical synapses $\mathrm{Ca}_{\mathrm{v}} 3$ channels promote glutamate release but only under conditions that inhibit hyperpolarization activated (HCN) channels that mediate a depolarizing current (Huang et al 2011). HCN channels, which are expressed in amacrine cells (Koizumi et al 2004), could keep $\mathrm{Ca}_{\mathrm{v}} 3$ activity in check, much like $\mathrm{BK}$ does for $\mathrm{Ca}_{\mathrm{v}} 1.3$. It is interesting to speculate that $\mathrm{BK} / \mathrm{Ca}_{\mathrm{v}} 1.3$ and $\mathrm{HCN} / \mathrm{Ca}_{\mathrm{v}} 3$ complexes could be targeted to distinct 
varicosities, thus diversifying reciprocal outputs and augmenting the parallel processing capabilities of each A17 cell.

\subsection{2 $\mathrm{Ca}_{\mathrm{v}} 2$ channels regulate neurotransmitter release from starburst amacrine cells}

Starburst amacrine cells (SACs) are wide-field GABA-ergic amacrine cells and are the only interneurons of the retina that also produce acetylcholine as a neurotransmitter (Brecha et al 1988). SACs transform information received from bipolar inputs into directionally-selective inhibitory inputs to specific subtypes of retinal ganglion cells (Wei 2018). The mechanisms by which SACs compute direction selectivity involve $\mathrm{Ca}^{2+}$ signals in the distal dendrites of SACs, where synaptic outputs to RGCs are localized, and are favored by stimulus movement away from the soma (i.e., centrifugal) (Euler et al 2002, Lee \& Zhou 2006). Pharmacological evidence suggests that $\mathrm{Ca}_{\mathrm{v}} 2.1$ and $\mathrm{Ca}_{\mathrm{v}} 2.2$, but not $\mathrm{Ca}_{\mathrm{v}} 1$ or $\mathrm{Ca}_{\mathrm{v}} 3$, mediate $\mathrm{Ca}_{\mathrm{v}}$ currents in mouse SACs (Kaneda et al 2007) and rabbit (Lee et al 2010), which is generally supported by scRNA-seq (Fig.2C)(Yan et al 2020). Based on the actions of specific $\mathrm{Ca}_{\mathrm{v}} 2$ blockers, the release of GABA and acetylcholine from SACs is regulated primarily by $\mathrm{Ca}_{\mathrm{v}} 2.1$ and $\mathrm{Ca}_{\mathrm{v}} 2.2$, respectively (Lee et al 2010). The matching of particular $\mathrm{Ca}_{\mathrm{v}} 2$ subtypes to the type of neurotransmitter released could result from differences in the proximity of $\mathrm{Ca}_{\mathrm{v}} 2$ subtypes to the corresponding vesicle release sites and/or functional coupling to distinct presynaptic proteins that could be involved in exocytosis of GABA and acetylcholine (Dolphin \& Lee 2020, Liu et al 2018).

\subsection{Modulation of $\mathrm{Ca}_{v}$ channels and retinal function}

$\mathrm{Ca}_{v}$ channels are subject to diverse forms of modulation that can alter neuronal excitability and cause short- and long-lasting changes in synaptic strength (Dolphin \& Lee 2020). The underlying mechanisms are complex and can involve protein interactions with various $\mathrm{Ca}_{v}$ subunits, as well as alternative splicing and post-translational modifications.

\subsection{Retinal $\mathrm{Ca}_{v} 1$ channels exhibit limited $\mathrm{Ca}^{2+}$-dependent inactivation (CDI)}

$\mathrm{CDI}$ is a negative feedback regulation by incoming $\mathrm{Ca}^{2+}$ ions that is characteristic of $\mathrm{Ca}_{\mathrm{v}} 1$ and $\mathrm{Ca}_{\mathrm{v}} 2$ channels. The mechanism involves calmodulin $(\mathrm{CaM})$, which is pre-associated with a site (IQdomain) in the CTD of these channels, and is evident as faster decay of $I_{C a}$ compared to $\mathrm{Ba}^{2+}$ currents $\left(I_{B a}\right)$ (Fig.4A). $\mathrm{Ca}^{2+}$ binding to $\mathrm{CaM}$ initiates conformational changes in the channel protein that favor inactivation; $\mathrm{Ba}^{2+}$ binds poorly to CaM and so does not support CDI (Ben-Johny \& Yue 2014). While CDI generally causes $\mathrm{Ca}_{\mathrm{v}} 1$ channels to inactivate within milliseconds, $\mathrm{Ca}_{\mathrm{v}} 1$ channels in the retina can inactivate with a time course on the order of seconds (Barnes \& Hille 1989, Corey et al 1984, von Gersdorff \& Matthews 1996). Slow CDI of retinal $\mathrm{Ca}_{\mathrm{v}} 1$ channels is expected to support sustained neurotransmitter release that is characteristic of ribbon synapses of photoreceptors and bipolar cells (Pangrsic et al 2018) as well as glycinergic synapses formed between AII amacrine cells OFF cone bipolar cells (Balakrishnan et al 2015, Habermann et al 2003).

Why do retinal $\mathrm{Ca}_{\mathrm{v}} 1$ channels undergo little CDI? For $\mathrm{Ca}_{\mathrm{v}} 1.4$, the answer lies within a C-terminal modulatory domain (CTM) that competes with and/or modulates CaM binding to the channel. Via an intramolecular interaction with a proximal region in the CTD, the CTM suppresses CDI and inhibits the voltage dependence of activation (Singh et al 2006, Wahl-Schott et al 2006). In HEK293T cells transfected with $\mathrm{Ca}_{\mathrm{v}} 1.4$ containing the CTM, $I_{C a}$ hardly inactivates during a 1-s depolarization, similar to $I_{B a}$ (Fig.4B). 
However, alternative splicing in the CTD can disrupt the actions of the CTM (Tan et al 2012, Williams et al 2018). One $\mathrm{Ca}_{\mathrm{v}} 1.4$ splice variant expressed in human retina lacks exon 47 , which corresponds to a portion of the CTM $\left(\mathrm{Ca}_{\mathrm{v}} 1.4 \Delta \mathrm{ex} 47\right)$ (Haeseleer et al 2016). $\mathrm{Ca}_{\mathrm{v}} 1.4 \Delta \mathrm{ex} 47$ binds to CaM, and exhibits CDI and a hyperpolarizing shift in voltage-dependent activation compared to $\mathrm{Ca}_{\mathrm{v}} 1.4$ channels containing exon $47\left(\mathrm{Ca}_{\mathrm{v}} 1.4+\mathrm{ex} 47\right.$ ) (Williams et al 2018) (Fig.4B,C). Although also present in $\mathrm{Ca}_{\mathrm{v}} 1.3$, the CTM does not nullify CDI of these channels in transfected cells (Singh et al 2008, Singh et al 2006) (Fig.4A). Additional mechanisms could prolong opening of retinal $\mathrm{Ca}_{\mathrm{v}} 1.3$ channels such as RNA editing of the IQ-domain (Huang et al 2012) and interactions with proteins known to suppress CDI, as described below.

$\boldsymbol{A}$

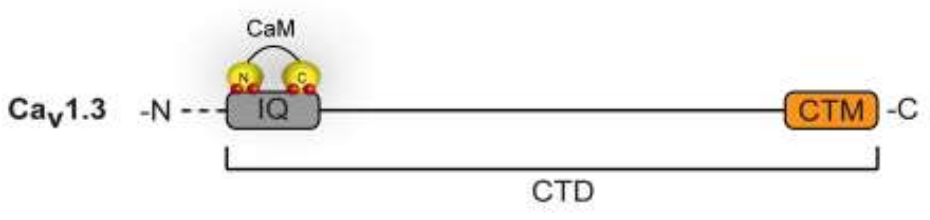

$\mathrm{Ca}_{\mathrm{v}} 1.3$

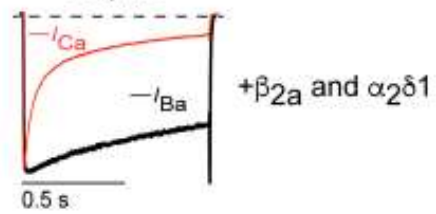

B
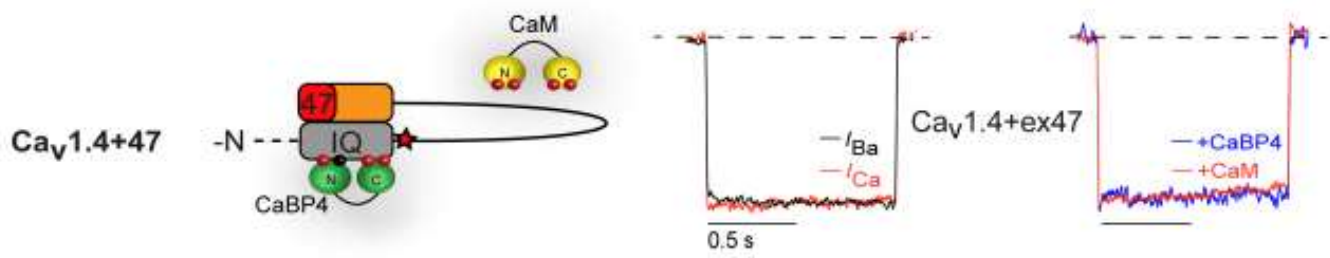

$+\beta_{2 \times 13}$ and $\alpha_{2} \delta 4$

C
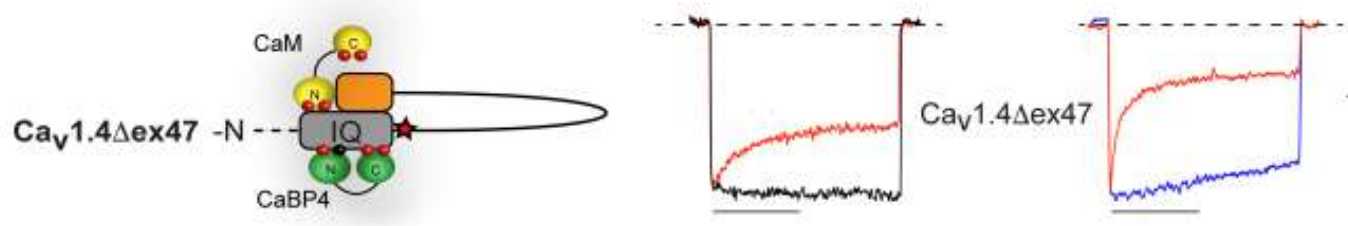

$+\beta_{2 \times 13}$ and $\alpha_{2} \delta 4$

D

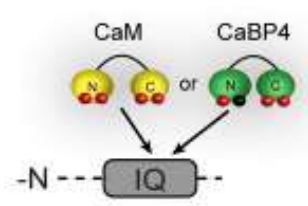

K1591X

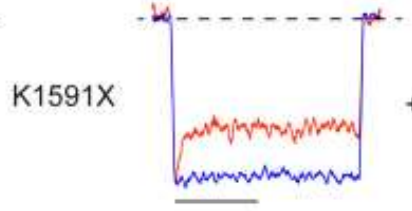

$+\beta_{2 \times 13}$ and $\alpha_{2} \delta 4$

Figure 4. CaM and CaBP4 modulation of Cav1 channels. Effects of $\mathrm{CaM}$ or $\mathrm{CaBP} 4$ binding to $\mathrm{Ca}_{\mathrm{v}} 1.3$ $(A)$ or $\mathrm{Ca}_{\mathrm{v}} 1.4(B-D)$ on $\mathrm{Ca}^{2+}$-dependent inactivation (CDI). Left panels show schematics of C-terminal domain (CTD) of each channel, containing IQ-domain and C-terminal modulatory domain (CTM). Right panels show normalized current traces in HEK293T cells expressing $\mathrm{Ca}_{\mathrm{v}} 1.3$ (A) or $\mathrm{Ca}_{\mathrm{v}} 1.4$ (B) with the indicated auxiliary subunits. In $B, C$, star indicates site of $\mathrm{K} 1591$. $A$, For $\mathrm{Ca}_{\mathrm{v}} 1.3$, CaM binding to the IQdomain (IQ) causes CDI, which is evident as faster decay of $I_{C a}$ compared to $I_{B a}$ (left traces). $B, \mathrm{Ca}_{\mathrm{v}} 1.4$ channels containing exon $47\left(\mathrm{Ca}_{\mathrm{v}} 1.4+\mathrm{ex} 47\right)$ undergo little $\mathrm{CDI}$ ( $I_{C a}$ is similar to $I_{B a}$, left traces) due to the action of the CTM in displacing CaM from the IQ-domain. CaBP4 binding to the IQ-domain has no effect on CDI in that $I_{C a}$ for $\mathrm{Ca}_{\mathrm{v}} 1.4+\mathrm{ex} 47$ alone (red) is similar to that when co-transfected with CaBP4 (blue, right traces). $C, \mathrm{CaM}$ binding causes $\mathrm{Ca}_{\mathrm{v}} 1.4$ channels lacking exon $47\left(\mathrm{Ca}_{\mathrm{v}} 1.4 \Delta \mathrm{ex} 47\right)$ to undergo strong $\mathrm{CDI}$ (left traces). Due to $\mathrm{CaBP} 4$ binding, $I_{C a}$ decays more slowly in cells co-transfected with $\mathrm{CaBP} 4$ 
compared to cells transfected with $\mathrm{Ca}_{\mathrm{v}} 1.4 \Delta \mathrm{ex} 47$ (Right traces). $D$, The $\mathrm{K} 1591 \mathrm{X}$ mutation eliminates the CTM, which enables CaM binding and CDI (left traces). However, CaBP4 binding prevents CDI, resulting in little inactivation of $I_{C a}$ (right traces). Modified from (Haeseleer et al 2016, Williams et al 2018, Williams et al 2020).

\subsection{CaBPs: modulators of $\mathrm{Ca}_{v}$ channels in a subset of retinal cell-types}

CaBPs are a family of CaM-like proteins that are expressed in the brain and retina, and interact with and modulate $\mathrm{Ca}_{v}$ channels. For most $\mathrm{Ca}_{v} 1$ channels, CaBPs compete with CaM for binding to the IQ-domain and thereby suppress CDI (Hardie \& Lee 2016). CaBP4 is abundantly localized in photoreceptor synaptic terminals where it associates with Cav1.4 (Haeseleer et al 2004, Lee et al 2015). While it interacts with the IQ-domain, CaBP4 does not suppress CDI (Fig.4B), but causes a hyperpolarizing shift in activation voltages in Cav1.4+ex47 (Haeseleer et al 2004, Shaltiel et al 2012). In the absence of a functional CTM, Cav1.4 $\Delta$ ex47 undergoes significantly less CDI when bound to CaBP4 (Fig.4C)(Haeseleer et al 2016). These effects of CaBP4 on activation of Cav1.4+ex47 and inactivation of Cav1.4 4 ex47 likely support prolonged glutamate release at the relatively negative membrane potential of photoreceptors in darkness. CaBP4 KO mice exhibit impairments in rod and cone synapse structure, and greatly diminished ERG b-waves, which are consistent with loss-of function of Cav1.4 (Haeseleer et al 2004, Liu et al 2013b, Maeda et al 2005).

While CaBP4 is the only CaBP expressed in photoreceptors, additional CaBPs are expressed in other retinal cell-types. CaBP1 is expressed in OFF cone bipolar and amacrine cells, while CaBP2 is expressed in ON cone bipolar cells and a population of OFF cone bipolar cells that do not express CaBP1. Compared to wild-type mice, excitatory synaptic currents are decreased in ON RGCs of CaBP2 KO mice and increased in OFF RGCs of CaBP1 KO mice (Sinha et al 2016). CaBP5 is expressed in rod and cone (ON and OFF) bipolar cells in mouse and primate retina. In CaBP5 KO retina, ON RGCs exhibit $\sim 50 \%$ reduction in sensitivity to dim light flashes, which could result from impaired rod bipolar-All amacrine cell transmission (Rieke et al 2008). Although CaBP1, CaBP2 and CaBP5 all suppress CDI of Cav1 channels in heterologous expression systems (Rieke et al 2008, Schrauwen et al 2012, Zhou et al 2004), the direct actions of these $\mathrm{CaBPs}$ on $\mathrm{Ca}_{v}$ channel function in bipolar cells remain to be determined. CaBPs can interact with targets other than $\mathrm{Ca}_{v}$ channels, which in addition to impaired regulation of $\mathrm{Ca}_{v} \mathrm{Ca}^{2+}$ signals, could contribute to the retinal phenotypes in $\mathrm{CaBP} \mathrm{KO}$ mice.

\subsection{Proton-mediated inhibition of $\mathrm{Ca}_{\mathrm{v}} 1$ channels in cones}

Because the lumen of synaptic vesicles is acidic, exocytosis of neurotransmitter during heightened periods of neuronal activity can transiently acidify the synaptic cleft. As shown for Cav1 channels in other cell-types (Klockner \& Isenberg 1994), lowering of pH potently inhibits Cav1 channels by causing a positive shift in voltage-dependent activation in rods and cones (Barnes \& Bui 1991, Barnes et al 1993, DeVries 2001) as well as bipolar cells (Palmer et al 2003). pH-dependent inhibition of Cav1 manifests as a transient component of the Itrans, Ca during a step depolarization which recovers with a similar time course as postsynaptic responses and is blunted by maneuvers that prevent presynaptic glutamate release (i.e., substitution of extracellular $\mathrm{Ca}^{2+}$ with $\mathrm{Ba}^{2+}$ ). Along with other evidence, these results suggest that $I_{\text {trans, } C a}$ results from presynaptically released protons (DeVries 2001). Simultaneous patch-clamp recordings of Cav1 currents and membrane capacitance changes in isolated goldfish bipolar cell terminals 
revealed that $\mathrm{pH}$-dependent inhibition of $\mathrm{Cav} 1$ reduces exocytosis in ways that may prevent short-term depression of vesicular release (Palmer et al 2003).

As a proposed mechanism whereby horizontal cells produce lateral inhibition in the retina (Kramer \& Davenport 2015), feedback inhibition of cone Cav1 channels could originate from protons released by various sources in horizontal cells including epithelial $\mathrm{Na}^{+}$channels (Vessey et al 2005), vacuolar $\mathrm{H}^{+}$pump ATPases (Jouhou et al 2007), and/or $\mathrm{Na}^{+} / \mathrm{H}^{+}$exchangers (Grove et al 2019, Warren et al 2016). Single channel recordings of heterologously expressed Cav1 channels showed that proton block involves pore-lining glutamate residues that also mediate $\mathrm{Ca}^{2+}$ selectivity of these channels (Fig.1A). Proton binding to carboxylate side chains contributed by these residues is thought to compete with $\mathrm{Ca}^{2+}$, thus favoring a low-conductance state and decreased channel open probability (Chen et al 1996). These glutamate residues, and therefore the ability to be inhibited by protons, is conserved in other Cav channels that are expressed in bipolar and horizontal cells (Fig.2A,B). Thus, the accumulation of protons in the synaptic cleft could have complex actions on $\mathrm{Ca}_{\mathrm{v}}$ channels in the membrane of each cell-type contributing to this triadic synapse.

\subsection{Dysregulation of $\mathrm{Ca}_{\mathrm{v}} 1.4$ and vision disorders}

Studies of $C A C N A 1 F$ mutations involved in retinal disease have yielded important insights on the structure/function relationships of $\mathrm{Ca}_{\mathrm{v}}$ 1.4. $C A C N A 1 F$ is targeted by numerous $(>140)$ mutations that cause vision disorders which, besides CSNB2, include X-linked cone-rod dystrophy (CORDX3) (Jalkanen et al 2006), and Åland eye disease (Jalkanen et al 2007, Vincent et al 2011). Clinical phenotypes linked to $C A C N A 1 F$ mutations are heterogeneous and include moderate to severe night blindness, low visual acuity, myopia, nystagmus, and/or strabismus (Hove et al 2016). The variability in these symptoms could result from a complex interplay of how the mutations affect the intrinsic properties of $\mathrm{Ca}_{\mathrm{v}} 1.4$ and factors such as alternative splicing and protein interactions, which could modify the impact of the mutations on photoreceptor structure and function.

\subsection{Mutations that cause retinal disease have diverse effects on $\mathrm{Ca}_{\mathrm{v}} 1.4$ function}

Most disease-causing mutations in $C A C N A 1 F$ are expected to cause a loss of channel function (i.e., abolishing or reducing $\mathrm{Ca}_{\mathrm{v}} 1.4-$ mediated $\mathrm{Ca}^{2+}$ influx). For example, the mutation L1068P in the poreforming S5-S6 linker of domain III causes a positive shift in the voltage-dependence of activation and accelerated voltage-dependent inactivation (Hoda et al 2005). By impairing the opening of Ca 1.4 channels, L1068P could limit the levels of glutamate needed to silence ON bipolar cells in darkness, thereby decreasing the gain of the light response.

Some $C A C N A 1 F$ mutations cause a gain-of function in channel activity. The I745T mutation in the S6 helix of repeat II causes a major hyperpolarizing shift $(\sim-30 \mathrm{mV})$ in the half-maximal voltage of activation as well as slow inactivation (Hemara-Wahanui et al 2005). Males carrying the I745T mutation present with a severe form of CSNB2 characterized by congenital nystagmus, severe nonprogressive impairment of visual acuity, frequent hypermetropia, and in some cases, intellectual disability (Hope et al 2005). Insights into the mechanisms underlying these visual phenotypes have emerged from studies of I745T knock-in mice. In ERGs of these mice (Knoflach et al 2013, Liu et al 2013b, Regus-Leidig et al 2014), b-waves are detectable but strongly reduced, similar to the ERGs of humans bearing the analogous mutation (Hope et al 2005). The strong negative shift in activation voltages of I745T could cause channels to remain open despite light onset, thus limiting the dynamic range of photoreceptor responses. 


\section{2 $\mathrm{CaBP} 4$ and alternative splicing as modifiers of $C A C N A 1 F$ mutations}

Because of the complexity of the $\mathrm{Ca}_{\mathrm{v}} 1.4$ interactome (Fig.3B), a variety of $\mathrm{Ca}_{\mathrm{v}} 1.4$-interacting proteins could modify the impact of $C A C N A 1 F$ mutations on vision. For example, $\mathrm{K} 1591 \mathrm{X}$ is a CSNB2 mutation resulting in a premature truncation of the CTD just downstream of the IQ-domain of $\mathrm{Ca}_{\mathrm{v}} 1.4$ (Fig.4D). Predictably, the mutation results in strong CaM-driven CDI and a hyperpolarizing shift in the voltage-dependence of activation in transfected cells (Singh et al 2006, Williams et al 2018). However, $\mathrm{CaBP} 4$ is capable of competing with $\mathrm{CaM}$ and preventing CDI when co-expressed with $\mathrm{K} 1591 \mathrm{X}$ mutant channels (Williams and Lee, unpublished; Fig.4D). Thus, the pathological consequences of K1591X in is likely to result primarily from $\mathrm{Ca}^{2+}$ influx at abnormally negative voltages, rather than increasing CDI.

Alternative splicing is also known to alter the consequences of disease-causing mutations in $\mathrm{Ca}_{\mathrm{v}}$ encoding genes. For example, I745T causes $\mathrm{Ca}_{\mathrm{v}} 1.4 \Delta \mathrm{ex} 47$ to activate at even more negative voltages and to deactivate with slower kinetics as compared to $\mathrm{Ca}_{\mathrm{v}} 1.4+\mathrm{ex} 47$. Moreover, I745T causes a breakdown in the $\mathrm{Ca}^{2+}$ selectivity of $\mathrm{Ca}_{\mathrm{v}} 1.4 \Delta \mathrm{ex} 47$ but not in $\mathrm{Ca}_{\mathrm{v}} 1.4+\mathrm{ex} 47$ (Williams et al 2020). Because $\mathrm{Ca}_{\mathrm{v}} 1.4 \Delta \mathrm{ex} 47$ is expressed in human but not in rodent retina (Haeseleer et al 2016), the I745T knock-in mouse strain (Knoflach et al 2013, Liu et al 2013b, Regus-Leidig et al 2014) might not reflect some of the pathological sequelae of the mutation in the context of $\mathrm{Ca}_{\mathrm{v}} 1.4 \Delta \mathrm{ex} 47$.

\subsection{Do $\mathrm{Ca}_{\mathrm{v}} 1.4$ channelopathies result from defects in photoreceptor synapse structure and/or function?}

A conundrum arising from electrophysiological analysis of the $C A C N A 1 F$ mutations and studies of various mutant mouse strains is whether CSNB2 and related disorders might involve alterations in formation and/or maintenance of photoreceptor synapses during development rather than from aberrant function of $\mathrm{Ca}_{\mathrm{v}} 1.4$ at mature synapses. For example, the CSNB2 mutation W1440X results in the deletion of the entire CTD and loss of $\mathrm{Ca}_{\mathrm{v}} 1.4$ protein expression in Xenopus oocytes and HEK293 cells (Hoda et al 2005). Therefore, W1440X could lead to similar defects in rod and cone synapse formation as are characteristic of $\mathrm{Ca}_{\mathrm{v}} 1.4 \mathrm{KO}$ mice (Liu et al 2013b, Regus-Leidig et al 2014, Zabouri \& Haverkamp 2013). Similarly, defects in cone synapse structure associated with diminished levels of presynaptic $\mathrm{Ca}_{\mathrm{v}} 1.4$ channels in $\alpha_{2} \delta-4 \mathrm{KO}$ mice (Kerov et al 2018) (Fig.3C) could contribute to stationary or progressive cone dysfunction in individuals with loss-of function mutations in CACNA2D4 (Ba-Abbad et al 2015, Bacchi et al 2015, Wycisk et al 2006b).

Consistent with the role of CaBP4 in enhancing the activation of $\mathrm{Ca}_{\mathrm{v}} 1.4$ (Haeseleer et al 2004, Haeseleer et al 2016), CABP4 mutations cause CSNB2-like phenotypes (Bijveld et al 2013, Hove et al 2016). While a subset of photoreceptor synapses appear normal morphologically, synaptic ribbons are shorter and often localized ectopically with some sprouting of horizontal and bipolar cell neurites in the ONL (Haeseleer et al 2004, Liu et al 2013b, Maeda et al 2005). Similar abnormalities are seen in I745T knock-in mice (Knoflach et al 2015, Liu et al 2013b, Regus-Leidig et al 2014). Thus, either loss-of function or gain-of function in $\mathrm{Ca}_{\mathrm{v}} 1.4$ may lead to destabilization of photoreceptor synapse structure. In this context, it is noteworthy that decreasing $\mathrm{Ca}^{2+}$ levels in photoreceptors with $\mathrm{Ca}^{2+}$ chelators or sustained light exposure can disrupt the integrity of synaptic ribbons (Regus-Leidig et al 2010, Spiwoks-Becker et al 2004) and presynaptic clustering $\mathrm{Ca}_{\mathrm{v}} 1.4$ and RIM2 (Dembla et al 2020).

\section{Summary points}

1. $\mathrm{Ca}_{\mathrm{v}} 1.3$ and $\mathrm{Ca}_{\mathrm{v}} 1.4$ are the major $\mathrm{Ca}_{\mathrm{v}} 1$ subtypes in the retina and play predominantly presynaptic roles. Their unique properties (e.g., rapid activation at relatively negative 
voltages and slow inactivation) are well-suited to supporting sustained neurotransmitter release at ribbon and non-ribbon synapses.

2. $\mathrm{Ca}_{\mathrm{v}} 2$ channels are expressed primarily in the interneurons of the retina as well as RGCs, where they have been implicated in regulating the release of various neurotransmitters.

3. $\mathrm{Ca}_{\mathrm{v}} 3$ channels are prominently expressed in all retinal cell-types except photoreceptors. The contributions of $\mathrm{Ca}_{\mathrm{v}} 3$ channels are expected to be evident primarily under hyperpolarizing conditions that relieve their inactivation.

4. Alternative splicing and protein interactions diversify the intrinsic properties of $\mathrm{Ca}_{v}$ channels, as well as the impact of mutations that cause retinal disease.

Future issues:

1. Molecular mechanisms that regulate the localization and function of $\mathrm{Ca}_{\mathrm{v}}$ channels in retinal celltypes are largely unknown and yet critical for our understanding of how these channels contribute to visual processing. The use of in vivo electroporation and viruses to express recombinant $\mathrm{Ca}_{\mathrm{v}}$ channels in a cell-specific manner will help identify determinants within $\mathrm{Ca}_{\mathrm{v}}$ channels that enable their trafficking to discrete microdomains and allow them to optimally control processes such as neurotransmitter release.

2. scRNA-seq has revealed a broad cellular distribution of the different $\mathrm{Ca}_{\mathrm{v}}$ subtypes in the retina. Defining the retinal functions of $\mathrm{Ca}_{\mathrm{v}}$ channels will require new tools such as mouse strains with conditional $\mathrm{KO}$ of $\mathrm{Ca}_{\mathrm{v}}$ subtypes in specific retinal cell-types. In addition, anti-Ca $\mathrm{V}_{\mathrm{v}}$ antibodies with greater sensitivity and specificity than those that are currently available will enable methods such as SDS-digested freeze-fracture replica labelling electron microscopy to probe the nanoscale organization of $\mathrm{Ca}_{\mathrm{v}}$ channels.

3. In general, the available $\mathrm{Ca}_{\mathrm{v}} 1.4$ mutant mouse strains exhibit more severe retinal and visual phenotypes than individuals harboring mutations in genes encoding $\mathrm{Ca}_{\mathrm{v}}$ subunits or $\mathrm{Ca}_{\mathrm{v}}$ 1.4interacting proteins. Given the potential for species differences in gene expression patterns and alternative splicing events affecting $\mathrm{Ca}_{\mathrm{v}} 1.4$, the use of stem-cell derived retinal cell-types or organoid culture systems could provide important insights into the pathophysiology of $\mathrm{Ca}_{\mathrm{v}} 1.4$ channelopathies in humans, as well as new therapeutic advances.

\section{Disclosure statement}

The authors are not aware of any affiliations, memberships, funding, or financial holdings that might be perceived as affecting the objectivity of this review.

\section{Acknowledgements}

The authors are indebted to Drs. Wenjun Yan and Joshua Sanes for preparation of Figure 2 and advice on the scRNA-seq analysis, Dr. Joshua Singer for advice on bipolar cell synapses, and Kate Randall for input on earlier versions of the text. This work was supported by NIH grants R01 EY026817 and R03 NS115653 (to AL), F32 EY029953 (to JWM), F31 EY026477 (to BW) and T32HD040127 and a Burroughs Wellcome Postdoctoral Enrichment Award (to BW). 


\section{Literature cited}

Altier C, Garcia-Caballero A, Simms B, You H, Chen L, et al. 2011. The Cavbeta subunit prevents RFP2-mediated ubiquitination and proteasomal degradation of L-type channels. Nat Neurosci 14: $173-80$

Ba-Abbad R, Arno G, Carss K, Stirrups K, Penkett CJ, et al. 2015. Mutations in CACNA2D4 Cause Distinctive Retinal Dysfunction in Humans. Ophthalmology 123: 668-71

Bacchi N, Messina A, Burtscher V, Dassi E, Provenzano G, et al. 2015. A New Splicing Isoform of Cacna2d4 Mimicking the Effects of c.2451insC Mutation in the Retina: Novel Molecular and Electrophysiological Insights. Invest Ophthalmol Vis Sci 56: 4846-56

Balakrishnan V, Puthussery T, Kim MH, Taylor WR, von Gersdorff H. 2015. Synaptic Vesicle Exocytosis at the Dendritic Lobules of an Inhibitory Interneuron in the Mammalian Retina. Neuron 87: 563-75

Ball SL, Powers PA, Shin HS, Morgans CW, Peachey NS, Gregg RG. 2002. Role of the $\beta_{2}$ subunit of voltage-dependent calcium channels in the retinal outer plexiform layer. Invest Ophthalmol Vis Sci 43: 1595-603

Barnes S, Bui Q. 1991. Modulation of calcium-activated chloride current via $\mathrm{pH}$-induced changes of calcium channel properties in cone photoreceptors. J. Neurosci. 11: 4015-23

Barnes S, Hille B. 1989. Ionic channels of the inner segment of tiger salamander cone photoreceptors. J.Gen.Physiol. 94: 719-43

Barnes S, Merchant V, Mahmud F. 1993. Modulation of transmission gain by protons at the photoreceptor output synapse. Proc. Natl. Acad. Sci. U. S. A. 90: 10081-5

Baylor DA, Fuortes MG, O'Bryan PM. 1971. Receptive fields of cones in the retina of the turtle. $J$. Physiol. 214: 265-94

Bech-Hansen NT, Naylor MJ, Maybaum TA, Pearce WG, Koop B, et al. 1998. Loss-of-function mutations in a calcium-channel $\mathrm{a}_{1}$-subunit gene in Xp11.23 cause incomplete X-linked congenital stationary night blindness. Nature Genet. 19: 264-67

Ben-Johny M, Yue DT. 2014. Calmodulin regulation (calmodulation) of voltage-gated calcium channels. J. Gen. Physiol. 143: 679-92

Bijveld MM, Florijn RJ, Bergen AA, van den Born LI, Kamermans M, et al. 2013. Genotype and phenotype of 101 dutch patients with congenital stationary night blindness. Ophthalmology 120: 2072-81

Blanks JC, Adinolfi AM, Lolley RN. 1974. Synaptogenesis in the photoreceptor terminal of the mouse retina. J Comp Neurol 156: 81-93

Brecha N, Johnson D, Peichl L, Wassle H. 1988. Cholinergic amacrine cells of the rabbit retina contain glutamate decarboxylase and gamma-aminobutyrate immunoreactivity. Proc. Natl. Acad. Sci. U. S. A. 85: 6187-91

Brockhaus J, Schreitmuller M, Repetto D, Klatt O, Reissner C, et al. 2018. alpha-Neurexins Together with alpha2delta-1 Auxiliary Subunits Regulate $\mathrm{Ca}(2+)$ Influx through Cav2.1 Channels. $J$. Neurosci. 38: 8277-94

Buraei Z, Yang J. 2013. Structure and function of the beta subunit of voltage-gated $\mathrm{Ca}^{2+}$ channels. Biochim Biophys Acta 1828: 1530-40

Busquet P, Nguyen NK, Schmid E, Tanimoto N, Seeliger MW, et al. 2010. CaV1.3 L-type Ca2+ channels modulate depression-like behaviour in mice independent of deaf phenotype. Int $J$ Neuropsychopharmacol 13: 499-513 
Cao Y, Sarria I, Fehlhaber KE, Kamasawa N, Orlandi C, et al. 2015. Mechanism for Selective Synaptic Wiring of Rod Photoreceptors into the Retinal Circuitry and Its Role in Vision. Neuron 87: 124860

Cassidy JS, Ferron L, Kadurin I, Pratt WS, Dolphin AC. 2014. Functional exofacially tagged N-type calcium channels elucidate the interaction with auxiliary $\alpha 2 \delta-1$ subunits. Proc. Natl. Acad. Sci. U. S. A. 111: 8979-84

Chang B, Heckenlively JR, Bayley PR, Brecha NC, Davisson MT, et al. 2006. The nob2 mouse, a null mutation in Cacnalf: anatomical and functional abnormalities in the outer retina and their consequences on ganglion cell visual responses. Vis Neurosci 23: 11-24

Chavez AE, Singer JH, Diamond JS. 2006. Fast neurotransmitter release triggered by Ca influx through AMPA-type glutamate receptors. Nature 443: 705-8

Chen XH, Bezprozvanny I, Tsien RW. 1996. Molecular basis of proton block of L-type Ca2+ channels. J. Gen. Physiol. 108: 363-74

Cheong E, Shin HS. 2014. T-type Ca2+ channels in absence epilepsy. Pflugers Arch 466: 719-34

Choi SY, Jackman S, Thoreson WB, Kramer RH. 2008. Light regulation of Ca2+ in the cone photoreceptor synaptic terminal. Vis Neurosci 25: 693-700

Connaughton V. 1995. Glutamate and Glutamate Receptors in the Vertebrate Retina In Webvision: The Organization of the Retina and Visual System, ed. H Kolb, E Fernandez, R Nelson. Salt Lake City (UT)

Copenhagen DR, Jahr CE. 1989. Release of endogenous excitatory amino acids from turtle photoreceptors. Nature 341: 536-9

Corey DP, Dubinsky JM, Schwartz EA. 1984. The calcium current in inner segments of rods from the salamander (Ambystoma tigrinum) retina. J. Physiol. 354: 557-75

Country MW, Campbell BFN, Jonz MG. 2019. Spontaneous action potentials in retinal horizontal cells of goldfish (Carassius auratus) are dependent upon L-type $\mathrm{Ca}(2+)$ channels and ryanodine receptors. J Neurophysiol 122: 2284-93

Cui J, Ivanova E, Qi L, Pan ZH. 2012. Expression of CaV3.2 T-type Ca(2)(+) channels in a subpopulation of retinal type-3 cone bipolar cells. Neuroscience 224: 63-9

Dembla E, Dembla M, Maxeiner S, Schmitz F. 2020. Synaptic ribbons foster active zone stability and illumination-dependent active zone enrichment of RIM2 and Cav1.4 in photoreceptor synapses. Sci Rep 10: 5957

DeVries SH. 2001. Exocytosed protons feedback to suppress the Ca2+ current in mammalian cone photoreceptors. Neuron 32: 1107-17

Diamond JS. 2017. Inhibitory Interneurons in the Retina: Types, Circuitry, and Function. Annu Rev Vis Sci 3: 1-24

Dolphin AC. 2013. The $\alpha 2 \delta$ subunits of voltage-gated calcium channels. Biochim Biophys Acta 1828: 1541-9

Dolphin AC. 2016. Voltage-gated calcium channels and their auxiliary subunits: physiology and pathophysiology and pharmacology. J. Physiol. 594: 5369-90

Dolphin AC, Lee A. 2020. Presynaptic calcium channels: specialized control of synaptic neurotransmitter release. Nat Rev Neurosci

Eggers ED, Lukasiewicz PD. 2011. Multiple pathways of inhibition shape bipolar cell responses in the retina. Vis Neurosci 28: 95-108

Ertel EA, Campbell KP, Harpold MM, Hofmann F, Mori Y, et al. 2000. Nomenclature of voltage-gated calcium channels. Neuron 25: 533-5 
Euler T, Detwiler PB, Denk W. 2002. Directionally selective calcium signals in dendrites of starburst amacrine cells. Nature 418: 845-52

Euler T, Haverkamp S, Schubert T, Baden T. 2014. Retinal bipolar cells: elementary building blocks of vision. Nat Rev Neurosci 15: 507-19

Euler T, Masland RH. 2000. Light-evoked responses of bipolar cells in a mammalian retina. $J$ Neurophysiol 83: 1817-29

Famiglietti EV, Jr., Kolb H. 1975. A bistratified amacrine cell and synaptic cirucitry in the inner plexiform layer of the retina. Brain Res 84: 293-300

Feigenspan A, Ohs A, von Wittgenstein J, Brandstatter JH, Babai N. 2020. Analysis of tetrodotoxinsensitive sodium and low voltage-activated calcium channels in developing mouse retinal horizontal cells. Exp Eye Res 195: 108028

Fell B, Eckrich S, Blum K, Eckrich T, Hecker D, et al. 2016. $\alpha 2 \delta-2$ Controls the Function and TransSynaptic Coupling of $\mathrm{Ca}_{\mathrm{v}} 1.3$ Channels in Mouse Inner Hair Cells and Is Essential for Normal Hearing. J. Neurosci. 36: 11024-36

Geisler S, Schopf CL, Stanika R, Kalb M, Campiglio M, et al. 2019. Presynaptic alpha2delta-2 Calcium Channel Subunits Regulate Postsynaptic GABAA Receptor Abundance and Axonal Wiring. $J$. Neurosci. 39: 2581-605

Gregory FD, Bryan KE, Pangrsic T, Calin-Jageman IE, Moser T, Lee A. 2011. Harmonin inhibits presynaptic $\mathrm{Ca}_{\mathrm{v}} 1.3 \mathrm{Ca}^{2+}$ channels in mouse inner hair cells. Nat Neurosci 14: 1109-11

Grimes WN, Li W, Chavez AE, Diamond JS. 2009. BK channels modulate pre- and postsynaptic signaling at reciprocal synapses in retina. Nat Neurosci 12: 585-92

Grimes WN, Zhang J, Graydon CW, Kachar B, Diamond JS. 2010. Retinal parallel processors: more than 100 independent microcircuits operate within a single interneuron. Neuron 65: 873-85

Grimes WN, Zhang J, Tian H, Graydon CW, Hoon M, et al. 2015. Complex inhibitory microcircuitry regulates retinal signaling near visual threshold. J Neurophysiol 114: 341-53

Grove JCR, Hirano AA, de Los Santos J, McHugh CF, Purohit S, et al. 2019. Novel hybrid action of GABA mediates inhibitory feedback in the mammalian retina. PLoS biology 17: e3000200

Habermann CJ, O'Brien BJ, Wassle H, Protti DA. 2003. AII amacrine cells express L-type calcium channels at their output synapses. J. Neurosci. 23: 6904-13

Haeseleer F, Imanishi Y, Maeda T, Possin DE, Maeda A, et al. 2004. Essential role of $\mathrm{Ca}^{2+}$-binding protein 4, a $\mathrm{Ca}_{\mathrm{v}} 1.4$ channel regulator, in photoreceptor synaptic function. Nat Neurosci 7: 107987

Haeseleer F, Williams B, Lee A. 2016. Characterization of C-terminal Splice Variants of $\mathrm{Ca}_{\mathrm{v}} 1.4 \mathrm{Ca}^{2+}$ Channels in Human Retina. J. Biol. Chem. 291: 15663-73

Haq W, Arango-Gonzalez B, Zrenner E, Euler T, Schubert T. 2014. Synaptic remodeling generates synchronous oscillations in the degenerated outer mouse retina. Front Neural Circuits 8: 108

Hardie J, Lee A. 2016. Decalmodulation of Cav1 channels by CaBPs. Channels 10: 33-7

Hartveit E. 1999. Reciprocal synaptic interactions between rod bipolar cells and amacrine cells in the rat retina. J Neurophysiol 81: 2923-36

Hemara-Wahanui A, Berjukow S, Hope CI, Dearden PK, Wu SB, et al. 2005. A CACNA1F mutation identified in an X-linked retinal disorder shifts the voltage dependence of Cav1.4 channel activation. Proc. Natl. Acad. Sci. U. S. A. 102: 7553-58

Hoda JC, Zaghetto F, Koschak A, Striessnig J. 2005. Congenital stationary night blindness type 2 mutations S229P, G369D, L1068P, and W1440X alter channel gating or functional expression of Cav1.4 L-type Ca2+ channels. J. Neurosci. 25: 252-9 
Hope CI, Sharp DM, Hemara-Wahanui A, Sissingh JI, Lundon P, et al. 2005. Clinical manifestations of a unique X-linked retinal disorder in a large New Zealand family with a novel mutation in CACNA1F, the gene responsible for CSNB2. Clin Exp Ophthalmol 33: 129-36

Hove MN, Kilic-Biyik KZ, Trotter A, Gronskov K, Sander B, et al. 2016. Clinical Characteristics, Mutation Spectrum, and Prevalence of Aland Eye Disease/Incomplete Congenital Stationary Night Blindness in Denmark. Invest Ophthalmol Vis Sci 57: 6861-69

Huang H, Tan BZ, Shen Y, Tao J, Jiang F, et al. 2012. RNA editing of the IQ domain in $\mathrm{Ca}_{\mathrm{v}} 1.3$ channels modulates their $\mathrm{Ca}^{2+}$-dependent inactivation. Neuron 73: 304-16

Huang Z, Lujan R, Kadurin I, Uebele VN, Renger JJ, et al. 2011. Presynaptic HCN1 channels regulate Cav3.2 activity and neurotransmission at select cortical synapses. Nat Neurosci 14: 478-86

Jalkanen R, Bech-Hansen NT, Tobias R, Sankila EM, Mantyjarvi M, et al. 2007. A novel CACNA1F gene mutation causes Aland Island eye disease. Invest Ophthalmol Vis Sci 48: 2498-502

Jalkanen R, Mantyjarvi M, Tobias R, Isosomppi J, Sankila EM, et al. 2006. X linked cone-rod dystrophy, CORDX3, is caused by a mutation in the CACNA1F gene. J Med Genet 43: 699-704

Jenkins MA, Christel CJ, Jiao Y, Abiria S, Kim KY, et al. 2010. $\mathrm{Ca}^{2+}$-dependent facilitation of $\mathrm{Ca}_{\mathrm{v}} 1.3$ $\mathrm{Ca}^{2+}$ channels by densin and $\mathrm{Ca}^{2+} /$ calmodulin-dependent protein kinase II. J. Neurosci. 30: 5125 35

Jia S, Muto A, Orisme W, Henson HE, Parupalli C, et al. 2014. Zebrafish Cacnalfa is required for cone photoreceptor function and synaptic ribbon formation. Hum Mol Genet 23: 2981-94

Johnson JE, Jr., Perkins GA, Giddabasappa A, Chaney S, Xiao W, et al. 2007. Spatiotemporal regulation of ATP and Ca2+ dynamics in vertebrate rod and cone ribbon synapses. Mol Vis 13: 887-919

Jouhou H, Yamamoto K, Homma A, Hara M, Kaneko A, Yamada M. 2007. Depolarization of isolated horizontal cells of fish acidifies their immediate surrounding by activating V-ATPase. J. Physiol. 585: 401-12

Kaneda M, Ito K, Morishima Y, Shigematsu Y, Shimoda Y. 2007. Characterization of voltage-gated ionic channels in cholinergic amacrine cells in the mouse retina. $J$ Neurophysiol 97: 4225-34

Katiyar R, Weissgerber P, Roth E, Dorr J, Sothilingam V, et al. 2015. Influence of the $\beta_{2}$ Subunit of LType Voltage-Gated Cav Channels on the Structural and Functional Development of Photoreceptor Ribbon Synapses. Invest Ophthalmol Vis Sci 56: 2312-24

Kerov V, Laird JG, Joiner ML, Knecht S, Soh D, et al. 2018. alpha2delta-4 Is Required for the Molecular and Structural Organization of Rod and Cone Photoreceptor Synapses. J. Neurosci. 38: 6145-60

Kersten FF, van Wijk E, van Reeuwijk J, van der Zwaag B, Marker T, et al. Association of whirlin with Cav1.3 (alpha1D) channels in photoreceptors, defining a novel member of the usher protein network. Invest Ophthalmol Vis Sci 51: 2338-46

Kim D, Song I, Keum S, Lee T, Jeong MJ, et al. 2001. Lack of the burst firing of thalamocortical relay neurons and resistance to absence seizures in mice lacking alpha(1G) T-type $\mathrm{Ca}(2+)$ channels. Neuron 31: 35-45

Klockner U, Isenberg G. 1994. Calcium channel current of vascular smooth muscle cells: extracellular protons modulate gating and single channel conductance. J. Gen. Physiol. 103: 665-78

Knoflach D, Kerov V, Sartori SB, Obermair GJ, Schmuckermair C, et al. 2013. Ca 1.4 IT mouse as model for vision impairment in human congenital stationary night blindness type 2. Channels 7 : 503-13

Knoflach D, Schicker K, Glosmann M, Koschak A. 2015. Gain-of-function nature of Ca 1.4 L-type calcium channels alters firing properties of mouse retinal ganglion cells. Channels 9: 298-306 
Koizumi A, Jakobs TC, Masland RH. 2004. Inward rectifying currents stabilize the membrane potential in dendrites of mouse amacrine cells: patch-clamp recordings and single-cell RT-PCR. Mol Vis 10: $328-40$

Kolb H. 1995a. Outer Plexiform Layer In Webvision: The Organization of the Retina and Visual System, ed. H Kolb, E Fernandez, R Nelson. Salt Lake City (UT)

Kolb H. 1995b. Photoreceptors In Webvision: The Organization of the Retina and Visual System, ed. $\mathrm{H}$ Kolb, E Fernandez, R Nelson. Salt Lake City (UT)

Kolb H. 1995c. Roles of Amacrine Cells In Webvision: The Organization of the Retina and Visual System, ed. H Kolb, E Fernandez, R Nelson. Salt Lake City (UT)

Kramer RH, Davenport CM. 2015. Lateral Inhibition in the Vertebrate Retina: The Case of the Missing Neurotransmitter. PLoS biology 13: e1002322

Lana B, Page KM, Kadurin I, Ho S, Nieto-Rostro M, Dolphin AC. 2016. Thrombospondin-4 reduces binding affinity of $[(3) \mathrm{H}]$-gabapentin to calcium-channel alpha2delta-1-subunit but does not interact with alpha2delta-1 on the cell-surface when co-expressed. Sci Rep 6: 24531

Lee A, Wang S, Williams B, Hagen J, Scheetz TE, Haeseleer F. 2015. Characterization of Cav1.4 complexes $\left(\alpha_{1} 1.4, \beta_{2}\right.$, and $\left.\alpha_{2} \delta-4\right)$ in HEK293T cells and in the retina. J. Biol. Chem. 290: 150521

Lee S, Kim K, Zhou ZJ. 2010. Role of ACh-GABA cotransmission in detecting image motion and motion direction. Neuron 68: 1159-72

Lee S, Zhou ZJ. 2006. The synaptic mechanism of direction selectivity in distal processes of starburst amacrine cells. Neuron 51: 787-99

Liu H, Li L, Wang W, Gong J, Yang X, Hu Z. 2018. Spontaneous Vesicle Fusion Is Differentially Regulated at Cholinergic and GABAergic Synapses. Cell rep 22: 2334-45

Liu X, Hirano AA, Sun X, Brecha NC, Barnes S. 2013a. Calcium channels in rat horizontal cells regulate feedback inhibition of photoreceptors through an unconventional GABA- and $\mathrm{pH}-$ sensitive mechanism. J. Physiol. 591: 3309-24

Liu X, Kerov V, Haeseleer F, Majumder A, Artemyev N, et al. 2013b. Dysregulation of Ca 1.4 channels disrupts the maturation of photoreceptor synaptic ribbons in congenital stationary night blindness type 2. Channels 7: 514-23

Lu Q, Ivanova E, Ganjawala TH, Pan ZH. 2013. Cre-mediated recombination efficiency and transgene expression patterns of three retinal bipolar cell-expressing Cre transgenic mouse lines. Mol Vis 19: $1310-20$

Lubbert M, Goral RO, Satterfield R, Putzke T, van den Maagdenberg AM, et al. 2017. A novel region in the $\mathrm{CaV} 2.1$ alpha1 subunit $\mathrm{C}$-terminus regulates fast synaptic vesicle fusion and vesicle docking at the mammalian presynaptic active zone. Elife 6

Macosko EZ, Basu A, Satija R, Nemesh J, Shekhar K, et al. 2015. Highly Parallel Genome-wide Expression Profiling of Individual Cells Using Nanoliter Droplets. Cell 161: 1202-14

Maddox JW, Randall KL, Yadav RP, Williams B, Hagen J, et al. 2020. A dual role for Cav1.4 Ca(2+) channels in the molecular and structural organization of the rod photoreceptor synapse. Elife 9

Maeda T, Lem J, Palczewski K, Haeseleer F. 2005. A critical role of CaBP4 in the cone synapse. Invest Ophthalmol Vis Sci 46: 4320-27

Mansergh F, Orton NC, Vessey JP, Lalonde MR, Stell WK, et al. 2005. Mutation of the calcium channel gene Cacna1f disrupts calcium signaling, synaptic transmission and cellular organization in mouse retina. Hum Mol Genet 14: 3035-46

Marc RE, Jones BW, Anderson JR, Kinard K, Marshak DW, et al. 2007. Neural reprogramming in retinal degeneration. Invest Ophthalmol Vis Sci 48: 3364-71 
Matthews G, Fuchs P. 2010. The diverse roles of ribbon synapses in sensory neurotransmission. Nat Rev Neurosci 11: 812-22

Maximov A, Bezprozvanny I. 2002. Synaptic targeting of N-type calcium channels in hippocampal neurons. J. Neurosci. 22: 6939-52

Mills SL, Massey SC. 1991. Labeling and distribution of AII amacrine cells in the rabbit retina. J Comp Neurol 304: 491-501

Morgans CW. 2001. Localization of the alpha(1F) calcium channel subunit in the rat retina. Invest Ophthalmol Vis Sci 42: 2414-18

Niesen CE, Ge S. 1999. Chronic epilepsy in developing hippocampal neurons: electrophysiologic and morphologic features. Dev Neurosci 21: 328-38

Olson PA, Tkatch T, Hernandez-Lopez S, Ulrich S, Ilijic E, et al. 2005. G-protein-coupled receptor modulation of striatal $\mathrm{Ca}_{\mathrm{v}} 1.3 \mathrm{~L}$-type $\mathrm{Ca}^{2+}$ channels is dependent on a Shank-binding domain. $J$. Neurosci. 25: 1050-62

Palmer MJ, Hull C, Vigh J, von Gersdorff H. 2003. Synaptic cleft acidification and modulation of shortterm depression by exocytosed protons in retinal bipolar cells. J. Neurosci. 23: 11332-41

Pan ZH. 2000. Differential expression of high- and two types of low-voltage-activated calcium currents in rod and cone bipolar cells of the rat retina. J Neurophysiol 83: 513-27

Pan ZH. 2001. Voltage-activated Ca2+ channels and ionotropic GABA receptors localized at axon terminals of mammalian retinal bipolar cells. Vis Neurosci 18: 279-88

Pan ZH, Hu HJ, Perring P, Andrade R. 2001. T-type Ca(2+) channels mediate neurotransmitter release in retinal bipolar cells. Neuron 32: 89-98

Pangrsic T, Singer JH, Koschak A. 2018. Voltage-Gated Calcium Channels: Key Players in Sensory Coding in the Retina and the Inner Ear. Physiol Rev 98: 2063-96

Perez-Reyes E. 2003. Molecular physiology of low-voltage-activated t-type calcium channels. Physiol Rev 83: 117-61

Pfeiffer-Linn CL, Lasater EM. 1996. Whole cell and single-channel properties of a unique voltageactivated sustained calcium current identified in teleost retinal horizontal cells. J Neurophysiol 75: 609-19

Picaud S, Hicks D, Forster V, Sahel J, Dreyfus H. 1998. Adult human retinal neurons in culture: Physiology of horizontal cells. Invest Ophthalmol Vis Sci 39: 2637-48

Protti DA, Llano I. 1998. Calcium currents and calcium signaling in rod bipolar cells of rat retinal slices. J. Neurosci. 18: 3715-24

Raven MA, Orton NC, Nassar H, Williams GA, Stell WK, et al. 2008. Early afferent signaling in the outer plexiform layer regulates development of horizontal cell morphology. J Comp Neurol 506: 745-58

Reese BE, Raven MA, Stagg SB. 2005. Afferents and homotypic neighbors regulate horizontal cell morphology, connectivity, and retinal coverage. J. Neurosci. 25: 2167-75

Regus-Leidig H, Atorf J, Feigenspan A, Kremers J, Maw MA, Brandstatter JH. 2014. Photoreceptor degeneration in two mouse models for congenital stationary night blindness type 2. PLoS One 9: e86769

Regus-Leidig H, Specht D, Tom Dieck S, Brandstatter JH. 2010. Stability of active zone components at the photoreceptor ribbon complex. Mol Vis 16: 2690-700

Regus-Leidig H, Tom Dieck S, Specht D, Meyer L, Brandstatter JH. 2009. Early steps in the assembly of photoreceptor ribbon synapses in the mouse retina: the involvement of precursor spheres. $J$ Comp Neurol 512: 814-24 
Rieke F, Lee A, Haeseleer F. 2008. Characterization of Ca2+-binding protein 5 knockout mouse retina. Invest Ophthalmol Vis Sci 49: 5126-35

Satoh H, Aoki K, Watanabe SI, Kaneko A. 1998. L-type calcium channels in the axon terminal of mouse bipolar cells. Neuroreport 9: 2161-5

Schmitz Y, Witkovsky P. 1997. Dependence of photoreceptor glutamate release on a dihydropyridinesensitive calcium channel. Neuroscience 78: 1209-16

Schrauwen I, Helfmann S, Inagaki A, Predoehl F, Tabatabaiefar MA, et al. 2012. A mutation in CABP2, expressed in cochlear hair cells, causes autosomal-recessive hearing impairment. Am J Hum Genet 91: 636-45

Schubert T, Weiler R, Feigenspan A. 2006. Intracellular calcium is regulated by different pathways in horizontal cells of the mouse retina. $J$ Neurophysiol 96: 1278-92

Shaltiel L, Paparizos C, Fenske S, Hassan S, Gruner C, et al. 2012. Complex regulation of voltagedependent activation and inactivation properties of retinal voltage-gated $\mathrm{Ca}_{\mathrm{v}} 1.4 \mathrm{~L}$-type $\mathrm{Ca}^{2+}$ channels by $\mathrm{Ca}^{2+}$-binding protein 4 (CaBP4). J. Biol. Chem. 287: 36312-21

Shekhar K, Lapan SW, Whitney IE, Tran NM, Macosko EZ, et al. 2016. Comprehensive Classification of Retinal Bipolar Neurons by Single-Cell Transcriptomics. Cell 166: 1308-23 e30

Shi L, Chang JY, Yu F, Ko ML, Ko GY. 2017. The Contribution of L-Type Cav1.3 Channels to Retinal Light Responses. Front Mol Neurosci 10: 394

Singer JH, Diamond JS. 2003. Sustained Ca2+ entry elicits transient postsynaptic currents at a retinal ribbon synapse. J. Neurosci. 23: 10923-33

Singh A, Gebhart M, Fritsch R, Sinnegger-Brauns MJ, Poggiani C, et al. 2008. Modulation of voltageand $\mathrm{Ca} 2+$-dependent gating of CaV1.3 L-type calcium channels by alternative splicing of a Cterminal regulatory domain. J. Biol. Chem. 283: 20733-44

Singh A, Hamedinger D, Hoda JC, Gebhart M, Koschak A, et al. 2006. C-terminal modulator controls $\mathrm{Ca}^{2+}$-dependent gating of $\mathrm{Ca}_{\mathrm{v}} 1.4$ L-type $\mathrm{Ca}^{2+}$ channels. Nat Neurosci 9: 1108-16

Sinha R, Lee A, Rieke F, Haeseleer F. 2016. Lack of CaBP1/Caldendrin or CaBP2 Leads to Altered Ganglion Cell Responses. eNeuro 3

Soto F, Watkins KL, Johnson RE, Schottler F, Kerschensteiner D. 2013. NGL-2 regulates pathwayspecific neurite growth and lamination, synapse formation, and signal transmission in the retina. J. Neurosci. 33: 11949-59

Specht D, Wu SB, Turner P, Dearden P, Koentgen F, et al. 2009. Effects of presynaptic mutations on a postsynaptic Cacna1s calcium channel colocalized with mGluR6 at mouse photoreceptor ribbon synapses. Invest Ophthalmol Vis Sci 50: 505-15

Spiwoks-Becker I, Glas M, Lasarzik I, Vollrath L. 2004. Mouse photoreceptor synaptic ribbons lose and regain material in response to illumination changes. Eur J Neurosci 19: 1559-71

Strom TM, Nyakatura G, Apfelstedt-Sylla E, Hellebrand H, Lorenz B, et al. 1998. An L-type calciumchannel gene mutated in incomplete $\mathrm{X}$-linked congenital stationary night blindness. Nature Genet. 19: 260-63

Subramanyam P, Obermair GJ, Baumgartner S, Gebhart M, Striessnig J, et al. 2009. Activity and calcium regulate nuclear targeting of the calcium channel beta4b subunit in nerve and muscle cells. Channels 3: 343-55

Tadmouri A, Kiyonaka S, Barbado M, Rousset M, Fablet K, et al. 2012. Cacnb4 directly couples electrical activity to gene expression, a process defective in juvenile epilepsy. EMBOJ 31: 373044 
Tan GM, Yu D, Wang J, Soong TW. 2012. Alternative splicing at C terminus of $\mathrm{Ca}_{\mathrm{v}} 1.4$ calcium channel modulates calcium-dependent inactivation, activation potential, and current density. J. Biol. Chem. 287: 832-47

Taylor WR, Morgans C. 1998. Localization and properties of voltage-gated calcium channels in cone photoreceptors of Tupaia belangeri. Vis Neurosci 15: 541-52

Ueda Y, Kaneko A, Kaneda M. 1992. Voltage-dependent ionic currents in solitary horizontal cells isolated from cat retina. $J$ Neurophysiol 68: 1143-50

Van Hook MJ, Nawy S, Thoreson WB. 2019. Voltage- and calcium-gated ion channels of neurons in the vertebrate retina. Progress in retinal and eye research 72: 100760

Vessey JP, Stratis AK, Daniels BA, Da Silva N, Jonz MG, et al. 2005. Proton-mediated feedback inhibition of presynaptic calcium channels at the cone photoreceptor synapse. J. Neurosci. 25: 4108-17

Vincent A, Wright T, Day MA, Westall CA, Heon E. 2011. A novel p.Gly603Arg mutation in CACNA1F causes Aland island eye disease and incomplete congenital stationary night blindness phenotypes in a family. Mol Vis 17: 3262-70

von Gersdorff H, Matthews G. 1996. Calcium-dependent inactivation of calcium current in synaptic terminals of retinal bipolar neurons. J.Neurosci. 16: 115-22

Wahl-Schott C, Baumann L, Cuny H, Eckert C, Griessmeier K, Biel M. 2006. Switching off calciumdependent inactivation in L-type calcium channels by an autoinhibitory domain. Proc. Natl. Acad. Sci. U. S. A. 103: 15657-62

Waithe D, Ferron L, Page KM, Chaggar K, Dolphin AC. 2011. \{beta\}-Subunits Promote the Expression of CaV2.2 Channels by Reducing Their Proteasomal Degradation. The Journal of biological chemistry 286: 9598-611

Wang Y, Fehlhaber KE, Sarria I, Cao Y, Ingram NT, et al. 2017. The Auxiliary Calcium Channel Subunit alpha2delta4 Is Required for Axonal Elaboration, Synaptic Transmission, and Wiring of Rod Photoreceptors. Neuron 93: 1359-74 e6

Warren TJ, Van Hook MJ, Supuran CT, Thoreson WB. 2016. Sources of protons and a role for bicarbonate in inhibitory feedback from horizontal cells to cones in Ambystoma tigrinum retina. J. Physiol. 594: 6661-77

Wei W. 2018. Neural Mechanisms of Motion Processing in the Mammalian Retina. Annu Rev Vis Sci 4: 165-92

Williams B, Haeseleer F, Lee A. 2018. Splicing of an automodulatory domain in Cav1.4 Ca(2+) channels confers distinct regulation by calmodulin. J. Gen. Physiol. 150: 1676-87

Williams B, Lopez JA, Maddox JW, Lee A. 2020. Functional impact of a congenital stationary night blindness type 2 mutation depends on subunit composition of $\mathrm{Cav} 1.4 \mathrm{Ca}(2+)$ channels. J. Biol. Chem. 295: 17215-26

Wu J, Marmorstein AD, Striessnig J, Peachey NS. 2007. Voltage-dependent calcium channel CaV1.3 subunits regulate the light peak of the electroretinogram. J Neurophysiol 97: 3731-5

Wycisk KA, Budde B, Feil S, Skosyrski S, Buzzi F, et al. 2006a. Structural and functional abnormalities of retinal ribbon synapses due to Cacna2d4 mutation. Invest Ophthalmol Vis Sci 47: 3523-30

Wycisk KA, Zeitz C, Feil S, Wittmer M, Forster U, et al. 2006b. Mutation in the auxiliary calciumchannel subunit CACNA2D4 causes autosomal recessive cone dystrophy. Am J Hum Genet 79: 973-7

Xiao H, Chen X, Steele EC, Jr. 2007. Abundant L-type calcium channel Ca(v)1.3 (alpha1D) subunit mRNA is detected in rod photoreceptors of the mouse retina via in situ hybridization. Mol Vis 13: 764-71 
Yamamoto K, Kobayashi M. 2018. Opposite Roles in Short-Term Plasticity for N-Type and P/Q-Type Voltage-Dependent Calcium Channels in GABAergic Neuronal Connections in the Rat Cerebral Cortex. J. Neurosci. 38: 9814-28

Yan W, Mallory A, Laboulaye NM, Tran IE, Benhar I, Sanes JR. 2020. Molecular identification of sixty-three amacrine cell types completes a mouse retinal cell atlas. BioRxiv

Zabouri N, Haverkamp S. 2013. Calcium channel-dependent molecular maturation of photoreceptor synapses. PLoS One 8: e63853

Zeitz C, Robson AG, Audo I. 2015. Congenital stationary night blindness: an analysis and update of genotype-phenotype correlations and pathogenic mechanisms. Progress in retinal and eye research 45: 58-110

Zhou H, Kim SA, Kirk EA, Tippens AL, Sun H, et al. 2004. $\mathrm{Ca}^{2+}$-binding protein-1 facilitates and forms a postsynaptic complex with $\mathrm{Ca}_{\mathrm{v}} 1.2$ (L-type) $\mathrm{Ca}^{2+}$ channels. J. Neurosci. 24: 4698-708 